\title{
Characterization by liquid chromatography combined with mass spectrometry of monoclonal anti-IGF-1 receptor antibodies produced in $\mathrm{CHO}$ and $\mathrm{NSO}$ cells
}

\author{
Alain Beck ${ }^{\mathrm{a}, *}$, Marie-Claire Bussat ${ }^{\mathrm{a}}$, Nathalie Zorn ${ }^{\mathrm{b}}$, Virginie Robillard ${ }^{\mathrm{a}}$, Christine \\ Klinguer-Hamour ${ }^{a}$, Stéphane Chenu ${ }^{\mathrm{a}}$, Liliane Goetsch ${ }^{\mathrm{a}}$, Nathalie Corvaïa ${ }^{\mathrm{a}}$, \\ Alain Van Dorsselaer ${ }^{\mathrm{b}}$, Jean-François Haeuw ${ }^{\mathrm{a}}$ \\ ${ }^{a}$ Centre d'Immunologie Pierre Fabre (CIPF), 5 Avenue Napoléon III, 74160 Saint-Julien-en-Genevois, France \\ ${ }^{\mathrm{b}}$ Laboratoire de Spectrométrie de Masse Bio-Organique, UMR CNRS 7509, Ecole de Chimie, Polymères et Matériaux \\ (ECPM)-Université Louis Pasteur (ULP), 25 rue Becquerel, 67087 Strasbourg Cedex 2, France
}

Received 23 February 2004; received in revised form 7 June 2004; accepted 21 June 2004

\section{Abstract}

7H2HM is a new humanized recombinant monoclonal antibody (MAb) directed against insulin-like growth factor-1 receptor and produced in $\mathrm{CHO}$ cells. Homogeneity of intact antibody, reduced light and heavy chains, Fab and Fc fragments were investigated by analytical methods based on mass (SDS-PAGE, SEC), charge (IEF, C-IEX) and hydrophobicity differences (RP-HPLC, HIC) and compared side-by-side with A2CHM, produced in NS0 cells. Primary structures and disulfide bridge pairing were analyzed by microsequencing (Edman degradation), mass spectrometry (MALDI-TOF, ES-TOF) and peptide mapping after enzymatic digestion (Trypsin, endoprotease Lys-C, papain). The light chains demonstrated the expected sequences. The heavy chains yielded post-translational modifications previously reported for other recombinant humanized or human IgG1 such as N-terminal pyroglutamic acid, C-terminal lysine clipping and $N$-glycosylation for asparagine 297. More surprisingly, two-thirds of the 7H2HM heavy chains were shown to contain an additional 24-amino-acid sequence, corresponding to the translation of an intron located between the variable and the constant domains. Taken together these data suggest that $7 \mathrm{H} 2 \mathrm{HM}$ is a mixture of three families of antibodies corresponding (i) to the expected structure (17\%; $149297 \mathrm{Da} ; 1330$ amino acids), (ii) a variant with a translated intron in one heavy chains (33\%; $152878 \mathrm{Da} ; 1354$ amino acids) and (iii) a variant with translated introns in two heavy chains (50\%; $154459 \mathrm{Da} ; 1378$ amino acids), respectively. RP-HPLC is not a commonly used chromatographic method to assess purity of monoclonal antibodies but unlike to SEC and SDS-PAGE, was able to show and to quantify the family of structures present in $7 \mathrm{H} 2 \mathrm{HM}$, which were also identified by peptide mapping, mass spectrometry and microsequencing.

(C) 2004 Published by Elsevier B.V.

Keywords: CHO cells; NSO cells; Peptide mapping; Glycopeptide mapping; Recombinant monoclonal antibodies; Insulin-like growth factor-1 receptor

\footnotetext{
* Corresponding author. Tel.: +3345035 35 22; fax: +3345035 3590

E-mail address: alain.beck@pierre-fabre.com (A. Beck).
}

cations in oncology, organ transplantation, cardiac, rheumatologic, auto-immune and infectious diseases [6]. Seven of these antibodies gained approval in the area of cancer and many more are evaluated in clinical trials [7-9]. In the case of solid tumors, growth-factor receptors as well as growth factors are important targets as demonstrated by the success of Herceptin ${ }^{\mathrm{TM}} /$ trastuzumab, Erbitux ${ }^{\mathrm{TM}} /$ cetuximab and Avastin $^{\mathrm{TM}}$ /bevacizumab directed against HER2/neu (epidermal growth factor receptor 2), EGFR (epidermal growth fac- 
tor receptor 1) and VEGF (vascular endothelium growth factor), respectively [10].

Insulin-like growth factor type 1 receptor (IGF-1R) another tyrosine kinase receptor, has been shown to be involved in tumorigenesis and several studies indicate that a number of tumors like breast, colon and osteosarcoma, over-express this receptor $[11,12]$. We decided to evaluate the potential of selective blocking of this new target with an immunoglobulin (IgG). First, murine antibodies were generated in BALB/c mice by injecting a recombinant form of human IGF-1R extra-cellular domain. After various screens, a monoclonal antibody defined as 7C10 was identified and humanized by complementary determining regions (CDR) grafting on human IgG1 $\kappa$ frameworks [13]. All the biological data observed with these antibodies strongly suggest that the humanized antibody may be of high therapeutic interest for IGF-1R overexpressing tumors [14]. A first recombinant MAb namely 7H2HM was produced in a Chinese hamster ovary cell line (CHO) and used in in vitro and in vivo models. A second MAb namely A2CHM was generated in a more productive mouse myeloma NSO cell line [15,16], for further pre-clinical development.

IgG1 antibodies are tetrameric glycoproteins $(\cong 150 \mathrm{kDa})$ composed of two identical heavy chains $(\mathrm{HC} \cong 50 \mathrm{kDa})$ and two identical light chains ( $\mathrm{LC} \cong 25 \mathrm{kDa}$ ). Sixteen disulfide bridges and non-covalent interactions maintain their structure. The heavy and light chains are linked by one disulfide bond and the heavy chains by two disulfide bonds, all located in the small hinge domain, which also contain a papain cleavage site yielding two Fab $(\cong 50 \mathrm{kDa})$ and one $\mathrm{Fc}(\cong 50 \mathrm{kDa})$ fragments. The other 12 cystine bridges are intramolecular and delimit six different globular domains: one variable $\left(V_{\mathrm{L}}\right)$ and one constant for the light chains $\left(C_{\mathrm{L}}\right)$ and one variable $\left(V_{\mathrm{H}}\right)$ and three constant for the heavy chains $\left(C_{\mathrm{H}} 1, C_{\mathrm{H}} 2\right.$ and $\left.C_{\mathrm{H}} 3\right)$ [5].

In this study, we report the extensive side-by-side characterization of both 7H2HM (CHO) and A2CHM (NSO) antibodies using electrophoresis, IsoElectric focusing, liquid chromatography, mass spectrometry and micro sequencing. We also discuss the strengths and the weaknesses of these different methods to show, to quantify and to identify expected as well as unexpected post-translational modifications.

\section{Experimental}

\subsection{Recombinant antibodies expression, production and purification}

The dhfr-CHO Dux-B11 cell line was maintained in alphaMEM supplemented with $10 \%$ fetal calf serum, $4 \mathrm{mM}$ glutamine (Invitrogen, Cergy Pontoise, France). For transfection, $10 \mu \mathrm{g}$ of plasmid, were co-transfected into $10^{7}$ cells by electroporation ( $1400 \mathrm{~V}, 25 \mu \mathrm{Fd}$, Gene-Pulser Biorad). $\mathrm{Dhfr}^{+} / \mathrm{Neo}^{+}$Transformants were selected in alpha MEM without ribo- and deoxyribonucleotides, $10 \%$ dialyzed fe- tal calf serum, $4 \mathrm{mM}$ glutamine, $500 \mu \mathrm{g} / \mathrm{ml}$ geneticin (Invitrogen, Cergy Pontoise, France) and Methotrexate (MTX, Sigma). MTX was used for gene amplification at a starting concentration of $50 \mathrm{nM}$ and was progressively increased to a final concentration of $200 \mathrm{nM}$ to select for amplified lines. Clone $7 \mathrm{H} 2$ was isolated in the selection medium and adapted in serum-free medium (ProCHO-5 CDM, Cambrex) for the anti-human IGF-1R antibody production. The GS-NS0 line (Lonza, Slough, UK) was grown in DMEM supplemented with $10 \%$ dialyzed fetal calf serum (Invitrogen, Cergy Pontoise, France), $4 \mathrm{mM}$ glutamine. Plasmid (40 $\mu \mathrm{g}$ ) was electroporated into $10^{7}$ cells as previously described by [17]. Isolated colonies were expanded and supernatants were screened for expression of functional antibodies by ELISA [17]. Clone A2C was selected for a specific productivity and was adapted in suspension and in serum-free medium, HyQSFM4Mab (Hyclone, UK) was supplemented with GS supplement and cholesterol lipid concentrate (Invitrogen, Cergy Pontoise, France).

Humanized anti-IGF-1R antibodies 7H2HM and A2CHM were purified from $\mathrm{CHO}$ and NSO cell supernatants, respectively. After concentration by ultra-filtration, a fourstep chromatography process was used, including affinitychromatography (Protein A Sepharose), cation-exchange (SP Sepharose HP), anion-exchange (Q Sepharose HP) and sizeexclusion chromatography (Superdex 200) [18,19]. All chromatography gels were supplied by Amersham Biosciences (Saclay, France).

\subsection{Sodium dodecyl sulfate-polyacrylamide gel} electrophoresis (SDS-PAGE)

SDS-PAGE electrophoresis was performed with reduced ( $\beta$-mercapto-ethanol) and non-reduced samples of antibodies, on $12 \%$ homogeneous Novex minigels (Invitrogen, Cergy Pontoise, France). One and five microgram of each antibody were analyzed and the gel was stained with Coomassie blue.

\subsection{IsoElectric focusing (IEF)}

The samples were analyzed by IEF on Pharmacia Phastsystem (Amersham, Orsay, France). The minigels rehydratation buffer was performed with urea $8.68 \mathrm{M}$, added with Sorbitol 10\% (w/v) and triton X1000.2\% (v/v). After sonication, ampholytes (7-9) (Biorad, Ivry-sur-Seine, France) were added on the basis of $0.4 \mathrm{ml}$ for $5 \mathrm{ml}$. Spots were deposed at $1 \mu \mathrm{g}$ for $4 \mu \mathrm{l}$. Standards of pI 5-10.5 (Amersham, Orsay, France) were settled in parallel. Coomassie blue was used for staining.

$N$-glycosidase $F$ digestion (PNGase F): $0.5 \mathrm{M}$ sodium phosphate, $\mathrm{pH} 7.5$ buffer was added to the samples at a $1 / 9(\mathrm{v} / \mathrm{v})$ ratio. PNGase $\mathrm{F}$ (EC 3.2.218, from Flavobacterium meningosepticum BioLabs, Ozyme, Saint-Quentinen-Yvelines, France,) was added at a ratio of $5 \mathrm{U}$ for $10 \mu \mathrm{g}$ protein and incubated at $37^{\circ} \mathrm{C}$ for $24 \mathrm{~h}$ with agitation. 


\subsection{Size-exclusion chromatography (SEC)}

Native MAbs were analyzed by SEC on a TSK gel G4000SWXL, $7.8 \mathrm{~mm} \times 300 \mathrm{~mm}$ (Tosoh Bioscience, VWR, Fontenay-sous-Bois, France) using a Waters HPLC system (Waters, Saint-Quentin-en-Yvelines, France) consisting of two 510 pumps, a 717 auto-injector and a 490 UV detector. The mobile phase was PBS DUBELCO (Polylabo, Strasbourg, France). The flow rate was $0.5 \mathrm{ml} / \mathrm{min}$ and the elution isocratic. The column temperature was ambient and the elution monitored at 210 and $280 \mathrm{~nm}$.

\subsection{Reverse-phase high-performance liquid chromatography (RP-HPLC)}

Analysis of intact MAbs by RP-HPLC were performed on a PLRP-S $8 \mu \mathrm{m} 1000 \AA$ A $2.1 \mathrm{~mm} \times 50 \mathrm{~mm}$ polymeric column (Polymer Laboratories, Interchim, Montluçon, France) using an Alliance system (pump: Waters 2695/UV spectrometer: Waters 996; Waters, Saint-Quentin-en-Yvelines, France). Approximately $10 \mu \mathrm{g}$ of sample were injected. The flow rate was $0.25 \mathrm{ml} / \mathrm{min}$ and the gradient conditions were used as follows: solvent A was water/acetic acid: 90/10 (v/v) and solvent B was acetonitrile, the gradient started with $100 \%$ solvent A mobile phase, which was linearly increased to $100 \%$ solvent $\mathrm{B}$ in $100 \mathrm{~min}$. The column temperature was $60^{\circ} \mathrm{C}$. Elution was monitored by UV at 210 and $280 \mathrm{~nm}$.

\subsection{Cationic-exchange chromatography (C-IEX)}

The different isoforms of the MAbs were separated on a Dionex WCX-10 cation-exchange column, $4 \mathrm{~mm} \times 250 \mathrm{~mm}$ with a WCX-10 guard column $4 \mathrm{~mm} \times 50 \mathrm{~mm}$ (Dionex, Voisin-Le-Bretonneux, France) on a Waters HPLC system, consisting of two 510 pumps, a 717 auto-injector and a 490 UV detector (Waters, Saint-Quentin-en-Yvelines, France). Buffer A was prepared with $10 \mathrm{mM}$ phosphate, $\mathrm{pH} 7.0$ and buffer B with $10 \mathrm{mM}$ phosphate and $1 \mathrm{M} \mathrm{NaCl}, \mathrm{pH} 7.0$. The flow rate was $1 \mathrm{ml} / \mathrm{min}$. The amount of injected $\mathrm{IgG}$ was approximately $20 \mu \mathrm{g}$. The gradient for elution started with $96 \%$ solvent A during 4 min, then $4 \%$ solvent $B$ followed by a linear gradient of $4-15 \%$ solvent B during $30 \mathrm{~min}$. After elution, the column was washed with $75 \%$ solvent $\mathrm{B}$ for $9 \mathrm{~min}$ and equilibrated with $96 \%$ solvent A for $25 \mathrm{~min}$. Elution was monitored at $280 \mathrm{~nm}$.

Carboxypeptidase B digestion (CPB, EC 3.4.17.2 from pig pancreas): samples in PBS buffer $(1 \mathrm{mg} / \mathrm{ml})$ were diluted (v/v) with $10 \mathrm{mM}$ phosphate, pH 7.0 buffer. CPB (Roche Diagnostics, Meylan, France) was added at a $1 / 30(w / w)$ ratio and digestion was performed for $2 \mathrm{H}$ at $37^{\circ} \mathrm{C}$.

\subsection{Preparation of reduced and alkylated heavy and light chains}

Samples of 7H2HM and A2CHM in PBS buffer (1-2 mg/ $\mathrm{ml}$ ) were lyophilized then solubilized in Tris- $\mathrm{HCl} 100 \mathrm{mM}$;
$2 \mathrm{mM}$ EDTA; guanidine $\mathrm{HCl} 6 \mathrm{M}$; pH 8.0 buffer to a final concentration of $1 \mathrm{mg} / \mathrm{ml}$. Disulfide reduction was performed by incubating IgG solution with $10 \mathrm{mM}$ DTT for $1 \mathrm{~h}$ at $37^{\circ} \mathrm{C}$. Iodoacetamide was then added to a final concentration of $60 \mathrm{mM}$ and the reaction was allowed to proceed for $1 \mathrm{~h}$ at room temperature in the dark. The chains were separated on a TSK G3000SW size-exclusion column $7.8 \mathrm{~mm} \times 300 \mathrm{~mm}$ (Tosoh Bioscience, VWR, Fontenay-sousBois, France) using a Waters HPLC system (Waters, SaintQuentin-en-Yvelines, France) consisting of two 510 pumps, a 717 auto-injector and a $490 \mathrm{UV}$ detector. The mobile phase was $3.0 \mathrm{M}$ guanidine hydrochloride in $50 \mathrm{mM}$ sodium phosphate, $\mathrm{pH}$ 6.2. The flow rate was $1 \mathrm{ml} / \mathrm{min}$ and the elution was isocratic. The column temperature was ambient and the elution was monitored at $280 \mathrm{~nm}$. Fractions containing light and heavy chains were concentrated on Amicon Ultra centrifugal filter units. The nominal molecular weight cut-off was $10 \mathrm{kDa}$ for light chains and $30 \mathrm{kDa}$ for heavy chains (Millipore, Saint-Quentin-en-Yvelines, France) and was washed three times with $10 \%$ acetic acid.

\subsection{Fab and Fc fragment preparation and analyses} after papain cleavage and hydrophobic-interaction chromatography $(\mathrm{HIC})$

Samples of MAbs in PBS solution were diluted (v/v) with $270 \mathrm{mM}$ Tris, $4 \mathrm{mM}$ EDTA and $20 \mathrm{mM}$ cystein, $\mathrm{pH}$ 7.2. Papain (EC3.4.22.2, Roche, Meylan, France) was added at a 1:50 (w/w), papain/IgG ratio and digestions were proceeded for $1 \mathrm{~h} 30$ at $37^{\circ} \mathrm{C}$. Papain-digested fragments were eluted on a TSK gel Phenyl-5 PW, $7.5 \mathrm{~mm} \times 75 \mathrm{~mm}$ (Tosoh Bioscience, VWR, Fontenay-sous-Bois, France) using Waters system consisting of two 510 pumps, a 717 auto-injector, a column oven and a 490 UV detector. The flow rate was $1 \mathrm{ml} / \mathrm{min}$ and the column temperature was maintained at $40^{\circ} \mathrm{C}$. Buffer A consisted of $2 \mathrm{M}$ ammonium sulfate in buffer B (20 mM Tris and 20\% glycerol, $\mathrm{pH} 8.0)$. Antibody fragments of 7H2HM and A2CHM were separated with a 40-min linear gradient from 100 to $0 \%$ buffer A. The HIC column was washed with $100 \%$ B for 5 min following each run and equilibrated at the initial conditions for $10 \mathrm{~min}$ prior to injection. Elution was monitored by UV at $280 \mathrm{~nm}$.

\subsection{Matrix-assisted laser desorption/ionization time-of-fight mass spectrometry (MALDI-TOF-MS)}

The sample were concentrated and desalted on Microcon YM-30000 MXCO (Millipore, Saint-Quentin-en-Yvelines, France) with six-fold volume of acetic acid at $10 \%$. Calculated masses were obtained with MassLynx Biolynx ${ }^{\text {TM }}$ software (Waters, Saint-Quentin-en-Yvelines, France)

Molecular mass of the protein was determined on a Bruker (Bremen, Germany) BIFLEX matrix-assisted laser desorption/ionization time-of-flight (TOF) mass spectrometer, equipped with a SCOUT ${ }^{\mathrm{TM}}$ high-resolution optics and a grid-less reflector. This instrument had a maximum ac- 
celeration potential at $30 \mathrm{kV}$ and has been operated in the linear positive mode. Ionization was accomplished with the $337 \mathrm{~nm}$ beam from a nitrogen laser with a repetition rate of $3 \mathrm{~Hz}$. A camera set-up on a microscope allowed visualization of the sample crystallization homogeneity before measurements. Spectra were externally calibrated either with either mono, double and triple charged peaks of a horse heart myoglobin solution $(2 \mathrm{pmol} / \mu \mathrm{l})$ at $\mathrm{m} / \mathrm{z} 16952,8476$ and 5651, respectively (for enzymatic digestions) or with mono, double and triple charged peaks at $m / z 66431,33216$ and 22144 of a BSA solution $(25 \mathrm{pmol} / \mu \mathrm{l})$, respectively (for whole antibody). Sandwich method preparation was performed for MALDI analyses. $0.5 \mu$ l of $\alpha$-cyano-4-hydroxycinnamic acid (HCCA, Sigma, Saint-Quentin-Fallavier, France) saturated in acetone was placed on the probe tip. $0.5 \mu \mathrm{l}$ of $1 \%$ formic acid was deposed on matrix-crystallized bed. Then $0.5 \mu \mathrm{l}$ of protein, dissolved in 50/50 acetonitrile/water and $1 \%$ formic acid were deposed. Finally, $0.2 \mu 1$ of HCCA saturated in 50/50 = acetonitrile/water was deposed. The target was dried under atmospheric conditions and then washed with $2 \mu$ l of water and $1 \%$ formic acid removed after a few seconds using forced air.

\subsection{Electrospray ionisation mass spectrometry (ESI-MS)}

ESI-MS spectra were obtained on a LCT electrospraytime-of-flight (TOF) mass spectrometer (Micromass, Manchester, UK) equipped with a Z-spray ionization source and with a mass range of 2-45000. Samples were dissolved in aqueous $50 \%$ acetonitrile containing $1 \%$ formic acid at a final concentration of $2-10 \mathrm{pmol} / \mu \mathrm{l}$. Ten microliter aliquots were introduced into the ion-source at a flow rate of $6 \mu \mathrm{l} / \mathrm{min}$. The extraction cone voltage was usually set to $40 \mathrm{~V}$ and the source temperature to $80^{\circ} \mathrm{C}$. Data were acquired in the positive ionization mode. Calibration was performed in the positive ionization mode using the multiply charged ions produced by a separate injection of horse heart myoglobin at a concentration of $2 \mathrm{pmol} / \mu \mathrm{l}$ (Sigma, Saint-Quentin-Fallavier, France). The MaxEnt ${ }^{\mathrm{TM}}$ algorithm (Waters, Saint-Quentinen-Yvelines, France) used the method of maximum entropy, to produce true molecular mass spectra from multiply charged electrospray spectra [20].

\subsection{LCMS analysis}

LC-ES-MS analyses of peptide mixtures obtained by enzymatic digestion were carried out using an Alliance system (pump: Waters 2690/UV spectrometer: Waters 996, SaintQuentin-en-Yvelines, France) coupled to a LCT ES-TOF mass spectrometer (Micromass, Manchester, UK). RP-HPLC conditions involved gradient using two mobile phases. Solvent $A$ consisted of acidified water $(0.1 \%$ trifluoric acid) and solvent $\mathrm{B}$ of acetonitrile containing $0.08 \%$ trifluoric acid. The gradient stayed for $5 \mathrm{~min}$ at $0 \% \mathrm{~B}$, then was increased from 0 to $60 \%$ B in $60 \mathrm{~min}$, from 60 to $80 \%$ in $5 \mathrm{~min}$, and was fol- lowed by isocratic elution at $80 \% \mathrm{~B}$ during $5 \mathrm{~min}$. Peptides were separated on a reverse-phase column (AG 125/2.1 Nucleosil 300-5 C-18, Macherey-Nagel, Hoerd, France) with a flow rate of $0.25 \mathrm{ml} / \mathrm{min}$ and were detected at $214 \mathrm{~nm}$ extracted from a range of $200-300 \mathrm{~nm}$, by a Waters 996 photodiode-array detector. The column effluent was divided by a Valco T (Houston, TX) between mass spectrometer and UV detector with a split of $1 / 10$. The mass spectrometer was scanned over a mass range of $m / z=200-2000$ at 4 s per scan. Calibration was performed using multiply charged ions of a $2 \mathrm{pmol} / \mu \mathrm{l}$ solution of horse heart myoglobin.

\subsubsection{Trypsin digestion}

Buffer was prepared with $0.1 \mathrm{M}$ Tris/Tris-HCl; $0.02 \mathrm{M}$ $\mathrm{CaCl} 2 ; \mathrm{pH}$ 8.1. Sequencing grade trypsin was used (EC 3.4.21.4 from bovine pancreas, Roche Diagnostics, Meylan, France). Solution A: sample to digest was dried with SpeedVac and then $10 \mu l$ of acetonitrile and $40 \mu \mathrm{l}$ of buffer were added. Solution B: $25 \mu \mathrm{g}$ of trypsin were solubilized in $50 \mu \mathrm{l}$ of water Direct-Q ${ }^{\mathrm{TM}}(0.5 \mu \mathrm{g} / \mu \mathrm{l})$. Reaction: solution B was added to solution $\mathrm{A}$ (enzyme/substrate: $1 / 10$ to $1 / 100$ ratio, depending on the protein amount to digest). The sample was incubated at $37^{\circ} \mathrm{C}$ during $7 \mathrm{H}$ and then the reaction was stopped by adding $1 \mu l$ of trifluoroacetic acid.

\subsubsection{Endoprotease Lys-C digestion}

Buffer was prepared with $0.1 \mathrm{M}$ Tris/Tris-HCl; $0.02 \mathrm{M}$ $\mathrm{CaCl}_{2} ; \mathrm{pH}$ 8.1. Sequencing grade endoprotease Lys-C was used (EC 3.4.21.50 from Lysobacter enzymogenes, Roche Diagnostics, Meylan, France). Solution A: sample to digest was dried with Speed-Vac and then $10 \mu \mathrm{l}$ of acetonitrile and $40 \mu \mathrm{l}$ of buffer were added. Solution B: solubilization of $5 \mu \mathrm{g}$ endoprotase Lys-C in $50 \mu$ l of water Direct-Q ${ }^{\mathrm{TM}}(0.1 \mu \mathrm{g} / \mu \mathrm{l})$. Reaction: solution $\mathrm{B}$ was added to solution-A (enzyme/substrate: $1 / 10$ to $1 / 100$ ratio, depending on protein amount to digest). Incubation was performed at $37^{\circ} \mathrm{C}$ overnight and the reaction was stopped by adding $1 \mu l$ of trifluoroacetic acid.

\subsection{Edman degradation microsequencing and pyroglutamate aminopeptidase digestion}

Automated Edman degradation of several trypsin-digested peptides, whole $\operatorname{IgG}$ or heavy chains and detection of their phenylthiohydantoin derivatives $(\mathrm{PTH})$ were performed on a pulsed liquid automatic sequencer (Applied Biosystems, model 473A, Roissy, France).

\subsubsection{Pyroglutamate aminopeptidase digestion}

Buffer was prepared with $50 \mathrm{mM}$ sodium phosphate; 10 mM DTT; 1 mM EDTA, pH 7.2. Recombinant pyroglutamate aminopeptidase (EC 3.4.19.3 from Pyrococcus furiosis, Sigma, Saint-Quentin-Fallavier, France) was used. Solution A: sample to digest was dried with a Speed-Vac then solubilized with $100 \mu \mathrm{l}$ of buffer and sonicated. Solution B: enzyme was solubilized in $50 \mu \mathrm{l}$ of buffer. Reaction: $25 \mu \mathrm{l}$ of solution 
B was added to solution A (5 milli-units for nearly 50-100 $\mu \mathrm{g}$ of protein). Incubation was performed at $50^{\circ} \mathrm{C}$ during $6 \mathrm{H}$. Reaction was stopped by adding $1 \mu \mathrm{l}$ of trifluoroacetic acid. Purification with a PROSORB System allowed water washing to eliminate contaminants and directly concentrate the protein for sequence on PVDF membrane for automatic sequencing by Edman degradation.

\section{Results}

\subsection{Whole antibodies characterization}

$7 \mathrm{H} 2 \mathrm{HM}$ and $\mathrm{A} 2 \mathrm{CHM}$ were produced in recombinant $\mathrm{CHO}(0.5-1 \mathrm{mg} / \mathrm{l})$ and NS0 cells $(40-100 \mathrm{mg} / \mathrm{l})$, respectively, using serum-free media. After cell harvesting, supernatants were concentrated and purified by affinity-chromatography on protein A as a capture step to remove host cell proteins. Cation-exchange chromatography was used to remove aggregates, fragments and residual host-cell impurities. Anionexchange chromatography was used to separate negatively charged molecules such as DNA and endotoxins. Finally, size-exclusion chromatography was used as polishing step to remove traces of aggregates and to formulate the bulk purified antibodies $[18,19]$. The average yield for this fourstep chromatography process was $38 \%$ and $73 \%$ for $7 \mathrm{H} 2 \mathrm{HM}$ and A2CHM, respectively. Set-up and validation of analytical methods for quantification of residual protein A, host cell DNA [21] and host-cell proteins [22] are in progress.

Non-reduced 7H2HM and A2CHM appeared homogeneous by SDS-PAGE electrophoresis and no bands of lower apparent mass were visible (Fig. 1A). Under reducing conditions, both antibodies exhibited similar bands corresponding to light chains. Conversely two bands appeared with a heavier apparent mass for the most intense band of $7 \mathrm{H} 2 \mathrm{HM}$ heavy chain compared to A2CHM.

IsoElectric focusing (IEF) was used to determine both $7 \mathrm{H} 2 \mathrm{HM}$ and $\mathrm{A} 2 \mathrm{CHM}$ isoelectric points (pI) and to analyze the isoform profiles (Fig. 1B). A2CHM displayed a major band with an isoelectric point of 8.71 and two secondary bands, one more acid (8.66) and one more basic (8.80) also confirmed by capillary IsoElectric focusing [23-25] (data not shown). 7H2HM exhibited a different profile with five bands and lower isoelectric points $(8.75,8.66,8.60,8.53$ and 8.47). To investigate the hypothesis that the difference of patterns could be explained by a difference of glycosylation between $\mathrm{CHO}$ and $\mathrm{NS} 0$ cell expression systems, 7H2 HM and $\mathrm{A} 2 \mathrm{CHM}$ were submitted to a PNGase F digestion and analyzed by IEF
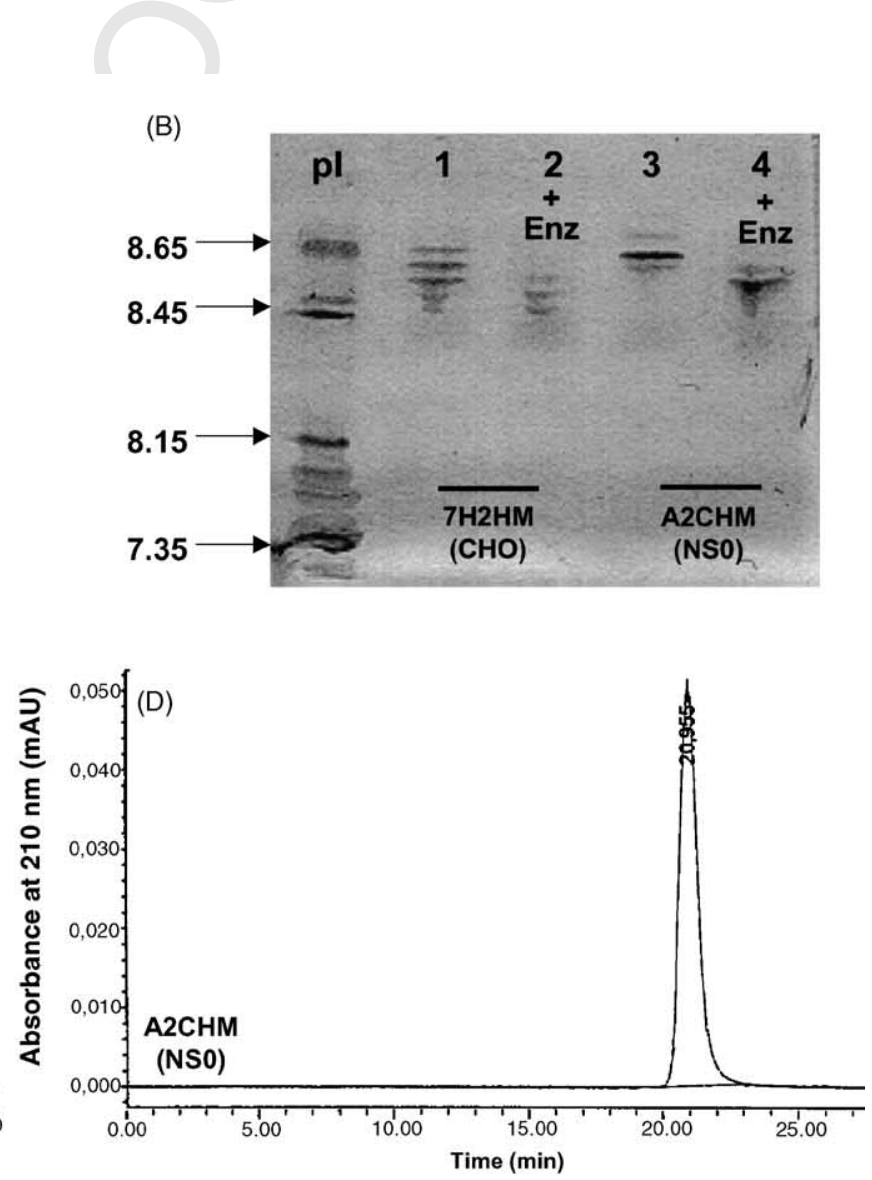
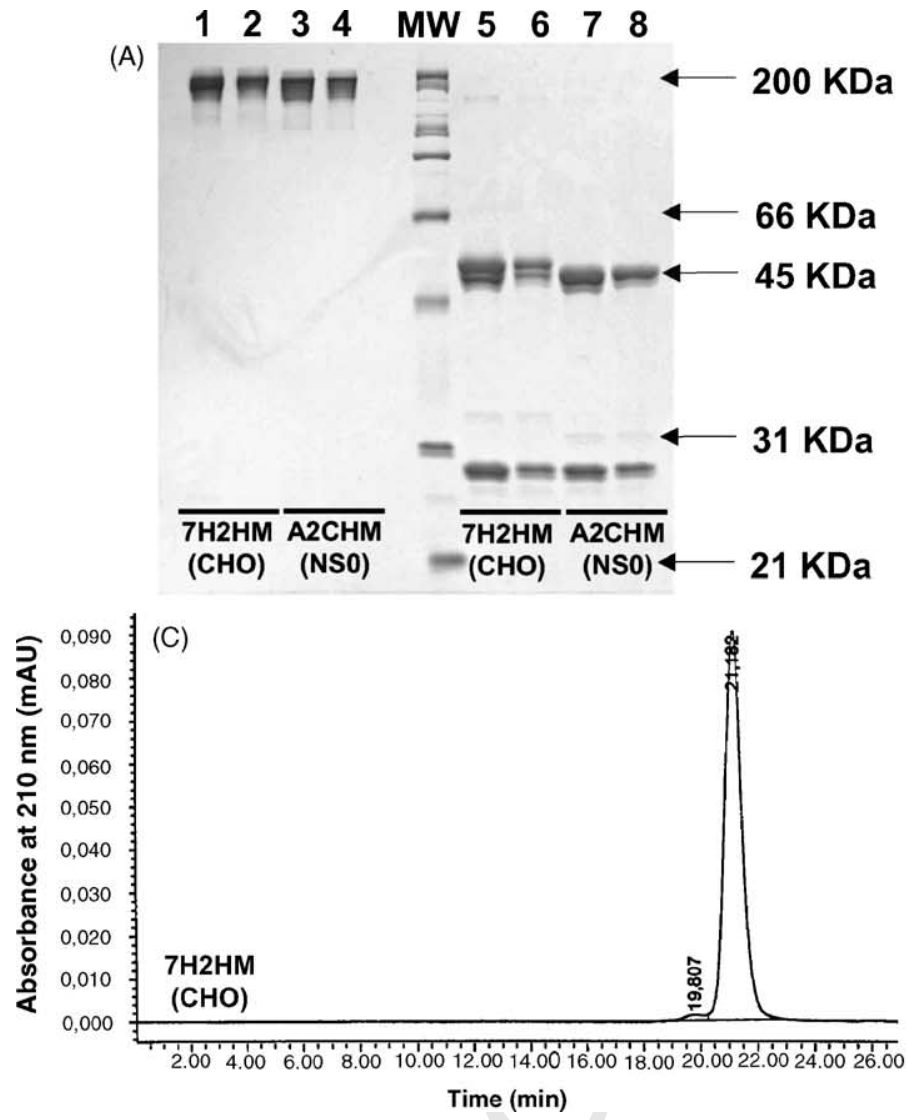

Fig. 1. Sodium dodecyl sulfate-polyacrylamid gel electrophoresis, IsoElectric focusing and size-exclusion chromatography. Both 7H2HM (lanes 1, 2, 5 and 6) and A2CHM (lanes 3, 4, 7 and 8) were analyzed as intact antibodies and as reduced light and heavy chains by SDS-PAGE (A); by IEF without (lanes 1 and 3) and with PNGase digestion (lanes 2 and 4) (B) and by SEC (C and D). 
(Fig. 1B) and by SDS-PAGE under non-reduced and reduced conditions (data not shown). The IEF gel showed an acidic shift for $7 \mathrm{H} 2 \mathrm{HM}$ and $\mathrm{A} 2 \mathrm{CHM}$ as expected, in agreement with the generation of negative charges by the -Asn(glycans)cleavage to -Asp(carboxylic acid). Three bands were observed for deglycosylated 7H2HM (8.61, 8.55 and 8.47) and two for deglycosylated A2CHM (8.65 and 8.60). The SDSPAGE gel did not show a difference for whole antibodies $(\cong 150 \mathrm{kDa})$ after $N$-deglycosylation, certainly because $2 \%$ difference of mass cannot be resolved for such large proteins. Conversely, a small shift was visible for the heavy chains $(\cong 50 \mathrm{kDa})$. As expected, no difference appeared for the light chains.

By size-exclusion chromatography (SEC) [26] A2CHM (Fig. 1D) appeared homogeneous without dimer while 7H2HM showed traces of dimer (Fig. 1C).

A reverse-phase high-performance liquid chromatography (RP-HPLC) method based on a polymeric column and heated at $60^{\circ} \mathrm{C}$ and adapted with a $10 \%$ acid acetic acid based eluant [27] confirmed the high homogeneity of A2CHM (Fig. 2B). Conversely, 7H2HM was separated in three peaks in a 17/33/50 ratio (Fig. 2A), under identical chromatographic conditions. An eluant with only $1 \%$ acetic acid or trifluoroacetic was not able to resolve these three peaks. Each peak was collected and submitted to MALDI-TOF mass analyses.
A2CHM displayed a mass in agreement with the expected one (experimental: $149875 \mathrm{Da}$; calculated: $149297 \mathrm{Da}$ ). The $7 \mathrm{H} 2 \mathrm{HM}$ principle peak demonstrated an excess of mass of approximately $6000 \mathrm{Da}$ (experimental: $156120 \mathrm{Da}$ ), the secondary peak an excess of mass of approximately $3000 \mathrm{Da}$ (experimental: $152755 \mathrm{Da}$ ) and the amount of collected material for the third peak was too low to perform a mass experiment.

Cationic-ion exchange chromatography (C-IEX) is a powerful separation technique previously reported for analysis and quantification of charge-variants with a resolution of one basic amino acid for more than 1300 amino acids in the case of IgG containing C-terminal lysines [25,28-30]. A2CHM exhibited a profile similar to those described for Humira ${ }^{\mathrm{TM}}$ /adalimumab (Fig. 2D). The main peak ( $85 \%$ and $7 \%$ acidic shoulder) was interpreted as a variant without lysines on both the heavy chains C-terminal ends, and the two more basic peaks as a variant with one lysine on one heavy chain (6\%) and the intact antibody with two C-terminal lysines (only $2 \%$ ). To confirm this hypothesis, a treatment with carboxypeptidase B and analysis by either C-IEX or IEF, allowed the removal of both more basic peaks on the chromatogram and bands on the gel $[28,30]$ (data not shown). As on the IEF gel, 7H2HM appeared more heterogeneous and was interpreted as containing more charged variants to be defined (Fig. 2C).
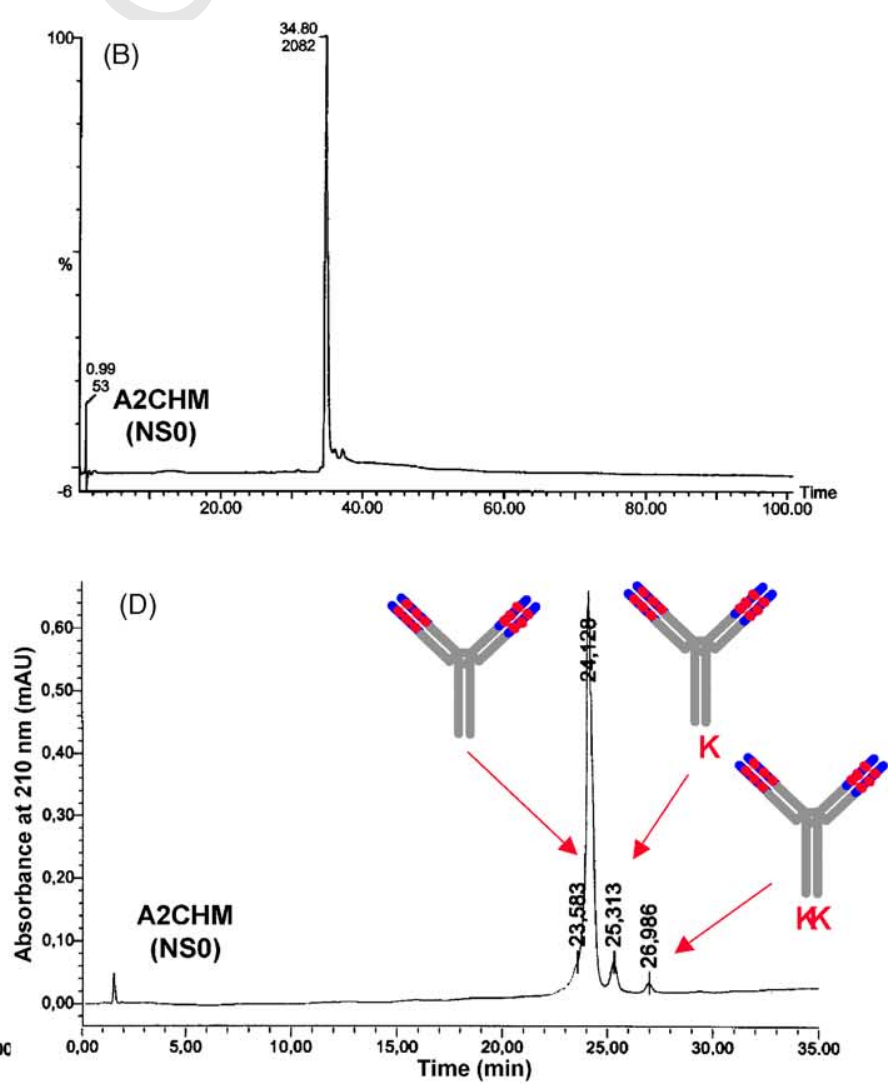
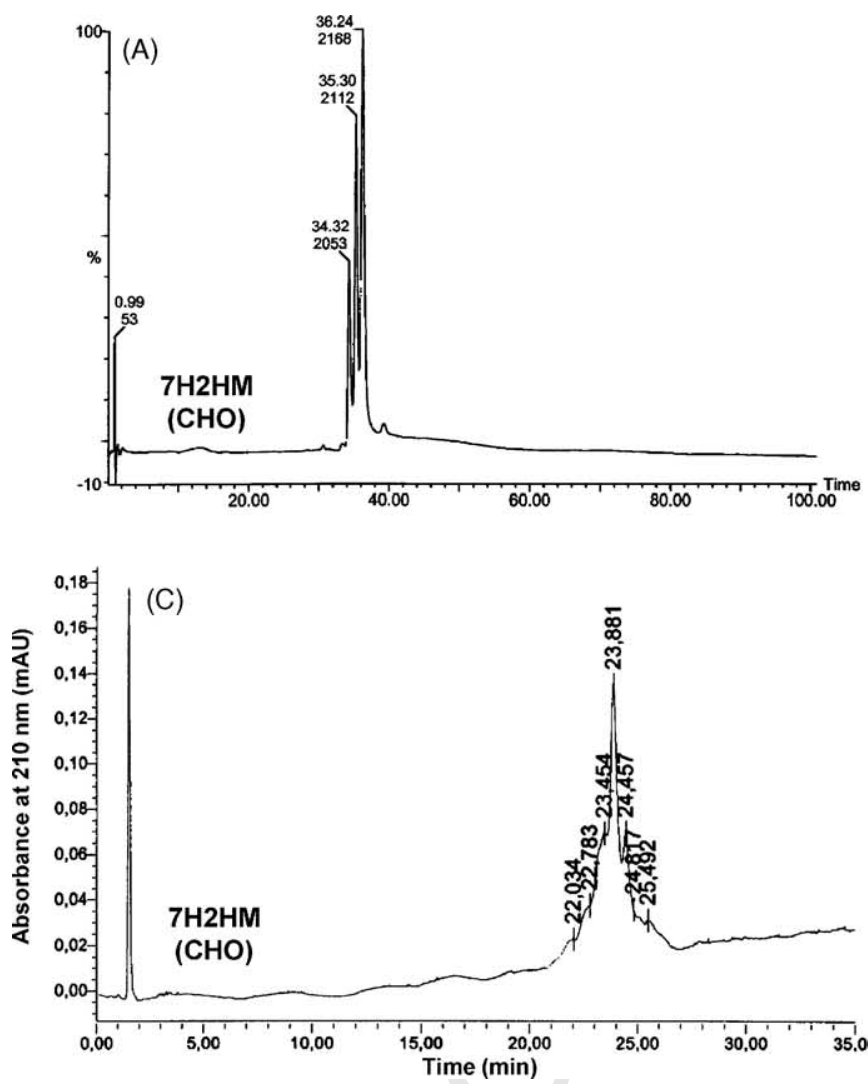

Fig. 2. Reverse-phase high-performance liquid chromatography and cationic-exchange chromatography. Both 7H2HM and A2CHM were analyzed by RPHPLC (A and B) and by C-IEX (C and D), respectively. In Fig. 2D, the main peak was interpreted as a variant without lysines on both the heavy chains C-terminal ends, and the two more basic peaks as a variant with one lysine on one heavy chain and the intact antibody with two C-terminal lysines. 

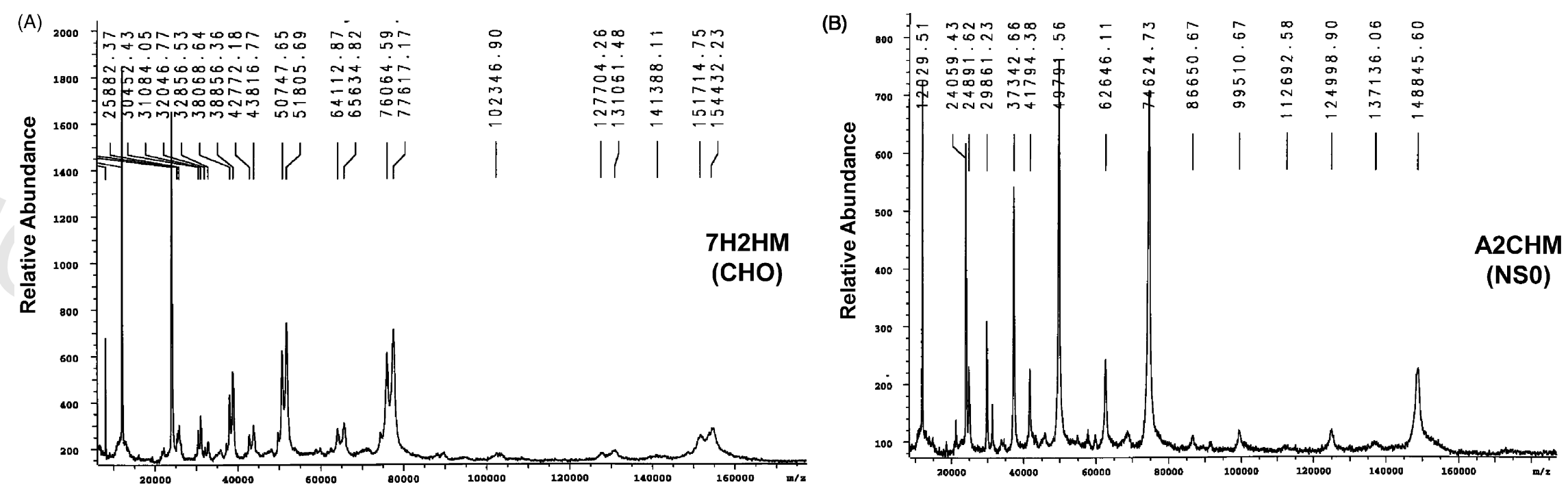

(C)
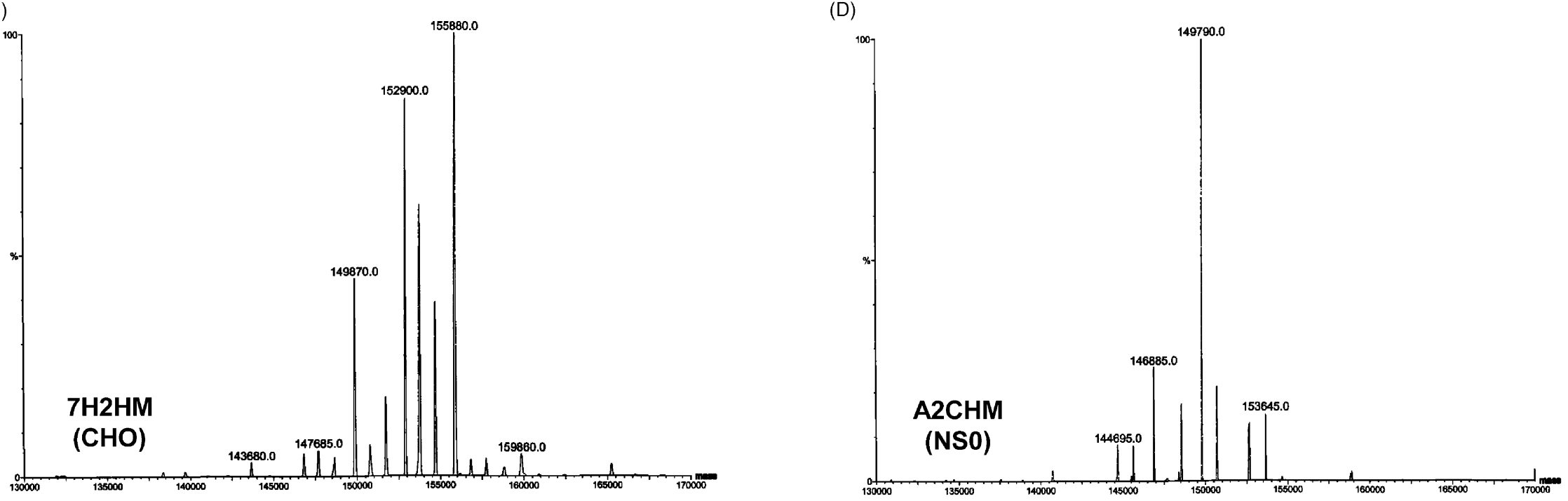
The intact antibody theoretical mass (149297 Da) was calculated assuming 16 disulfide bridges, heavy chains $\mathrm{N}$-terminal pyroglutamic acids formation $(-2 \times 18 \mathrm{Da})$, C-terminal lysine clipping $(-2 \times 128 \mathrm{Da})$ and Asn 297 "G1" type glycosylation [GlcNAc(Fuc)-GlcNAc-Man-(ManGlcNAc)-Man-GlcNAc-Gal: $+2 \times 1607 \mathrm{Da}$ ) as reported for another humanized IgG1 [4] and subsequently confirmed. Matrix-assisted laser desorption/ionization mass spectrometry [20] generates molecular ions of predominantly charge state $\left(\mathrm{MH}^{n+}\right.$ with $\left.n=1-4\right)$, which are generally detected with a mass accuracy of (+/-) $0.1 \%$, using a time-of-flight mass analyzer [31]. This was the case for A2CHM $(148845 \mathrm{Da} ; 74624 \times 2=149248 \mathrm{Da} ; 49791 \times$ $3=149373 \mathrm{Da} ; 37342 \times 4=149368 \mathrm{Da}$; average mass $=$ 149208 Da) (Fig. 3B). Experimental masses were obtained for three different batches with the same accuracy. The MALDI-TOF spectrum for 7H2HM (Fig. 3A) was different with at least two families of peaks with higher masses than those deduced from the theoretical sequence. Similar data were also observed for two additional batches.

Electrospray-ionization mass spectra (ESI-MS) were obtained for A2CHM and 7H2HM intact antibodies. The experimental mass obtained for A2CHM (149790 Da) was very close to the calculated mass $[149297 \mathrm{Da} / \Delta M=493 \mathrm{Da}$ $(0.1 \%)]$ (Fig. 3D). As previously shown by other analytical methods, 7H2HM appeared more heterogeneous with three main families of structures in a similar ratio as for the RPHPLC chromatogram: $155880 \mathrm{Da} / \Delta M=6583 \mathrm{Da}(4.4 \%)$; $152900 \mathrm{Da} / \Delta M=3603 \mathrm{Da}(2.4 \%) ; 149870 \mathrm{Da} / \Delta M=573 \mathrm{Da}$ (0.4\%) (Fig. 3C).

Direct N-terminal microsequencing by Edman degradation of the whole heterodimeric $7 \mathrm{H} 2 \mathrm{HM}$ antibody confirmed the presence of the expected ten first amino acids of the light chain (DIVMTQSPLS), however no signal was observed for the heavy chain (QVQLQESGPGQVQLQESGPG). Nterminal blocked heavy chain by a pyroglutamic acid (PyroGlu) resulting from the $\mathrm{N}$-terminal glutamine cyclization and loss of ammonia $(-17 \mathrm{Da})$ have been described for other IgG, [31-35] as well as for peptides [36,37].

Disulfide bridges pairing were investigated by MALDITOF and LC-MS after endoprotease Lys-C (Table 1) and trypsin digestion (data not shown). Due to the symmetry of IgGs only nine of the 16 disulfide bonds are unique and have been previously identified [34,38]. As shown in Table 1, for $7 \mathrm{H} 2 \mathrm{HM}$ three disulfide bonds were confirmed by MALDI-TOF and six by LC-MS. The more accurate and complete results were obtained for A2CHM with eight bonds confirmed by MALDI-TOF and five by LC-MS.

\subsection{Light and heavy chains characterization}

Size-exclusion chromatography (SEC) was used for analysis of reduced and alkylated light and heavy chains as well as a preparative method for the isolation of both monomers for primary structure confirmation (Fig. 4A,B). As expected the ratio of peak areas by UV detection was approximately 2 for 1 for the heavy $(\cong 50 \mathrm{kDa})$ and the light chains $(\cong 25 \mathrm{kDa})$, respectively. ESI-MS measures for $7 \mathrm{H} 2 \mathrm{HM}$ and $\mathrm{A} 2 \mathrm{CHM}$ reduced light chains isolated by SEC, were 24348.88 and $24348.26 \mathrm{Da}$ respectively, in full agreement with the calculated mass (24348 Da). The mass by MALDI-TOF of the reduced-alkylated heavy chain of A2CHM was found to be $51229 \mathrm{Da}$ for $51835 \mathrm{Da}$ calculated $(\Delta M=607 \mathrm{Da} ; 0.3 \%)$, assuming an $\mathrm{N}$-terminal PyroGlu ( $-18 \mathrm{Da})$, a C-terminal Lys clipping $(-128 \mathrm{Da})$ and a "G1" type glycoform $(+1607 \mathrm{Da})$ at $\mathrm{Asn}^{297}$. For the reduced-alkylated 7H2HM, two families of peaks were observed by MALDI-TOF with an average of $54671 \mathrm{Da}$ for the main product and $51256 \mathrm{Da}$ for the secondary product in approximately 2 for 1 ratio. Only the second mass fitted correspond to calculated one $(\Delta M=29 \mathrm{Da}$; $0.1 \%)$. The first mass exhibited an excess of $3442 \mathrm{Da}(6.7 \%)$.

The light chain contains 219 amino-acids and five Cys, with four Cys involved in two intra-molecular bridges $\left(\mathrm{Cys}^{23}-\mathrm{Cys}^{93}, \mathrm{Cys}^{139}{ }^{13} \mathrm{Cys}^{199}\right)$ for both variable and constant domains and one $\left(\mathrm{Cys}^{219-(\mathrm{HC})}\right)$, involved in an intermolecular disulfide bond with a heavy chain. Trypsin cleaves polypeptides after Lys or Arg residues excepted when they are followed by a Pro [39]. LC-MS tryptic maps of reduced and alkylated A2CHM and 7H2HM detected by UV at $280 \mathrm{~nm}$ and by mass spectrometry (TIC: total ion current; [20]), were similar. All 20 expected tryptic fragments were identified confirming the primary structure of the light chain (Table 2).

The primary structure characterization of $7 \mathrm{H} 2 \mathrm{HM}$ and $\mathrm{A} 2 \mathrm{CHM}$ heavy chain (447 amino acids, $\cong 50 \mathrm{kDa}$,
Table 1

7H2HM and A2CHM disulfide peptide mapping by mass-spectrometry

\begin{tabular}{|c|c|c|c|c|c|c|}
\hline \multirow[t]{2}{*}{ Endoprotease Lys-C } & \multirow[t]{2}{*}{ Fragments } & \multirow[t]{2}{*}{ Calculated mass } & \multicolumn{2}{|l|}{$7 \mathrm{H} 2 \mathrm{HM}$} & \multicolumn{2}{|l|}{ A2CHM } \\
\hline & & & LC-MS & MALDI & LC-MS & MALDI \\
\hline L-L Cys ${ }^{23}-$ Cys $^{93}(2 \times)$ & L1-3 & 9319.5 & n.d. ${ }^{a}$ & n.d. & 9319.8 & n.d. \\
\hline $\mathrm{H}-\mathrm{H} \mathrm{Cys}^{22}-\mathrm{Cys}^{96}(2 \times)$ & L1-5 & 9018.2 & n.d. & n.d. & n.d. & n.d. \\
\hline L-L Cys ${ }^{139}-$ Cys $^{199}(2 \times)$ & L7-8 & 7921.9 & 7921.9 & 7924.8 & 7921.7 & n.d. \\
\hline L-H Cys ${ }^{219}-$ Cys $^{220}(2 \times)$ & L11-13 & 1260.5 & 1261.2 & n.d. & 1260.9 & n.d. \\
\hline H-H Cys ${ }^{144}-$ Cys $^{200}(2 \times)$ & L6-12 & 3886.4 & 3886.4 & 3888.2 & 3886.3 & 3888.4 \\
\hline H-H Cys ${ }^{226}-\mathrm{Cys}^{226} / \mathrm{Cys}^{229}{ }^{22} \mathrm{Cys}^{229}$ & L12-12 & 5458.5 & n.d. & 5461.9 & 5458.5 & 5459.8 \\
\hline $\mathrm{H}-\mathrm{H} \mathrm{Cys}^{261}-\mathrm{Cys}^{321}(2 \times)$ & L13-17 & 3146.6 & n.d. & 3147.3 & 3146.3 & 3148.2 \\
\hline $\mathrm{H}-\mathrm{HCys}^{367}-\mathrm{Cys}^{425}(2 \times)$ & L23-27 & 4090.6 & n.d. & 4092.7 & 4090.5 & 4092.6 \\
\hline
\end{tabular}

a n.d., not determined. 

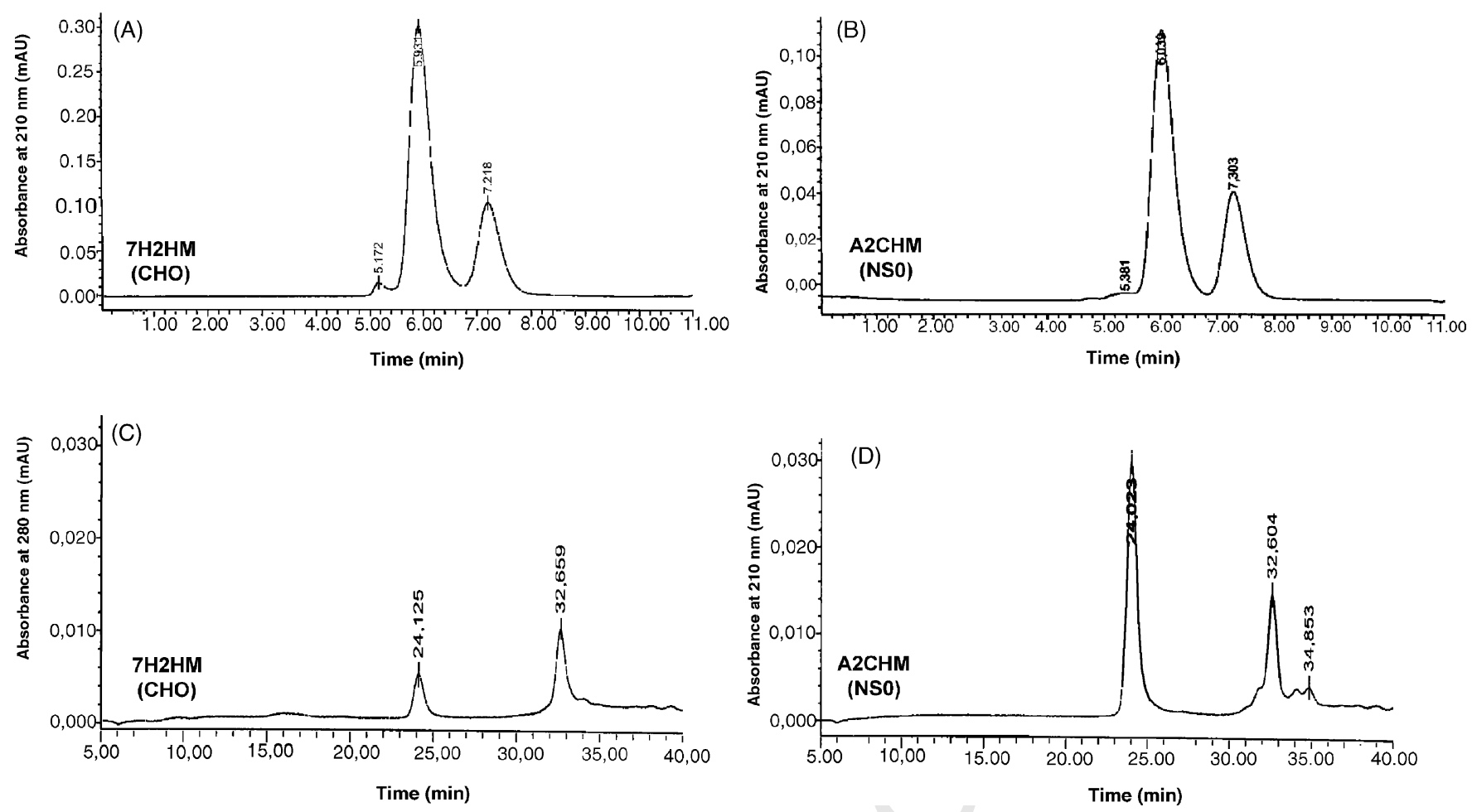

Fig. 4. Size-exclusion chromatography analysis of light and heavy chains and hydrophobic-interaction chromatography analysis of Fab and Fc fragments. Both 7H2HM and A2CHM reduced-alkylated light and heavy chains were analyzed and isolated by SEC (A and B). 7H2HM and A2CHM papain digested Fab and $\mathrm{Fc}$ fragments were analyzed and isolated by HIC (C and D).

several glycoforms, other post-translational modifications) was more complicated that for the structure of the light chain $(\cong 25 \mathrm{kDa})$. The heavy chain contains 11 cysteines (Cys $^{(22-96}, 144-200,220(-\mathrm{LC}), 226(-\mathrm{HC}), 229(-\mathrm{HC}), 261-321$ and 367-425) ) and 10 hot spots for modification which were carefully checked: (i) $\operatorname{Met}^{(4,252,} 358$ and 428) may be oxidized [40,41]; (ii) $\operatorname{Asn}^{(315,384)}$ may be deamidated (Asp) or isomerized (IsoAsp) and Asp (55, 280, 401) may be isomerized (IsoAsp) [42]; (iii) - Asn ${ }^{297}$-Ser-Thr( $N$-glycosylated consensus sequence); (iv) $\mathrm{N}$-terminal Gln ${ }^{1}$ (PyroGlu) [28]; and (v) C-terminal Lys ${ }^{447}$ clipped $[25,29]$.

Table 2

7H2HM and A2CHM light chains trypsin LC-MS maps

\begin{tabular}{|c|c|c|c|c|}
\hline Fragment & Sequence & $\begin{array}{l}\text { Calculated } \\
\text { mass }\end{array}$ & $\begin{array}{l}\text { Experimental mass } \\
7 \mathrm{H} 2 \mathrm{HM}(\mathrm{CHO})\end{array}$ & $\begin{array}{l}\text { Experimental mass } \\
\text { A2CHM(NS0) }\end{array}$ \\
\hline LT1 (1-24) & 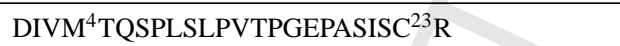 & 2555.3 & 2554.4 & 2555.4 \\
\hline LT2 (25-55) & SSQSIVHSN ${ }^{33} \mathrm{GN}^{35}$ TYLQWYLQKPGQSPQLLIYK & 3579.0 & 3579.1 & 3579.0 \\
\hline LT3 (56-59) & VSNR & 474.3 & 474.3 & 474.3 \\
\hline LT4 (60-66) & LYGVPDR & 818.4 & 818.5 & 818.5 \\
\hline LT5 (67-69) & FSGSGSGTDFTLK & 1302.6 & 1302.7 & 1302.7 \\
\hline LT6 (80-82) & ISR & 374.2 & 374.2 & 374.2 \\
\hline LT7 (83-108) & VEAEDVGVYYC ${ }^{93}$ FQGSHVPWTFGQGTK & 2962.3 & 2961.4 & 2962.2 \\
\hline LT8 (109-112) & VEIK & 487.3 & 487.3 & 487.3 \\
\hline LT8 + 9 (109-113) & VEIK-R & 643.4 & 643.4 & 643.4 \\
\hline LT10 (114-131) & TVAAPSVFIFPPSDEQLK & 1945.0 & 1945.1 & 1945.0 \\
\hline LT11 (132-147) & SGTASVVC ${ }^{139}$ LLNNFYPR & 1796.9 & 1797.0 & 1797.0 \\
\hline LT12 (148-150) & EAK & 346.2 & 346.2 & 346.2 \\
\hline LT13 (151-154) & VQWK & 559.3 & 559.3 & 559.3 \\
\hline LT14 (155-174) & VDNALQSGNSQESVTEQDSK & 2135.0 & 2135.0 & 2136.0 \\
\hline LT15 (175-188) & DSTYSLSSTLTLSK & 1501.8 & 1501.8 & 1501.8 \\
\hline LT16 (189-193) & ADYEK & 624.3 & 624.3 & 624.3 \\
\hline LT17 (194-195) & HK & 283.2 & 283.1 & 283.1 \\
\hline LT18 (196-212) & VYAC ${ }^{199}$ EVTHQGLSSPVTK & 1874.9 & 1875.5 & 1875.0 \\
\hline LT19 (213-216) & SFNR & 522.3 & 522.3 & 522.3 \\
\hline LT20 (217-219) & $\mathrm{GEC}^{219}$ & 364.1 & 364.1 & 364.1 \\
\hline
\end{tabular}


When the isolated heavy chain was submitted to pyroglutamate aminopeptidase digestion [43] and then Edman degradation, the expected sequence starting from the second $\mathrm{N}$ terminal amino acid was observed confirming the presence of N-terminal pyroglutamic acid.

The ultra-violet detection (UV) and total ion current (TIC) chromatograms produced during the analyses of the reducedalkylated heavy chain trypsin digests are presented in Fig. 5A and B (A2CHM) and Fig. 5C and D (7H2HM), respectively. The TIC mode of detection is very effective for the identification of small peptides containing only two, three or four amino acids, often not identified by UV (T6, T14, T38, T4, T16, T17, T22, T26, T27, T31, T25, T29, T9, T33). All the expected 40 peptides fragments were identified, some of them contained the previously described post-translational modifications at both N (T1) and C-termini (T40), as well as for the $\mathrm{Asn}^{297}$ containing nonapeptide T23 identified with an excess of mass, in agreement with complex asialo biantenary fucosylated carbohydrates for both 7H2HM and A2CHM (Table 3).

The main difference between both maps was a large peak mainly present in 7H2HM TIC LC-MS map (Fig. 5D) and corresponding in part to glycopeptides T23. This peak was isolated and submitted to Edman degradation. One of the determined sequences was "SHGTTSLAASTK" (calculated mass: 1160.3 Da; experimental mass: 1159.6 Da and confirmation by Edman degradation). This dodecapeptide did not belong to the heavy chain theoretical sequence but was a part of an intronic sequence present in the $\mathrm{CHO}$ vector between the variable and the constant domain (Fig. 6). This 24-amino-acid "intron" sequence (GEWILCAWAQLCPTPR-SHGTTSLA) is normally spliced and not translated but in the case of the $\mathrm{CHO}$ cell line used with the constructed vector for $7 \mathrm{H} 2 \mathrm{HM}$ expression [CHO Dux B11 (dhfr -/+) cells], it only occurred for approximately $33 \%$ of the heavy chains. The calculated mass of this 24 mer peptide is $2599 \mathrm{Da}$. It contains two Cys that may also be reduced and alkylated $(+2 \times 57 \mathrm{Da})$ during heavy chain analysis. The resulting mass $(2713 \mathrm{Da})$ approaches " $3000 \mathrm{Da}$ " excess of mass measured for the main part of 7H2HM heavy chain by MALDI-TOF and ESMS. The measured masses for 7H2HM corresponded well with newly calculated masses taking account the expression of this 24-amino-acid intron in one (experimental: $152088 \mathrm{Da}$; calculated: $151878 \mathrm{Da} ; \Delta M=210 \mathrm{Da} ; 0.1 \%$ ) or two heavy chains (experimental: $155126 \mathrm{Da}$; calculated: $154495 \mathrm{Da}$; $\Delta M=631 \mathrm{Da} ; 0.4 \%$ ) (Table 4).

The measured mass for the reduced, alkylated and isolated heavy chain also corresponded well with the newly calculated mass (experimental: $54671 \mathrm{Da}$; calculated: $53924 \mathrm{Da} ; \Delta M=$ $746 \mathrm{Da} ; 1.4 \%)$.

\subsection{Fab and Fc fragments characterization [28]}

Hydrophobic interaction chromatography (HIC) (Fig. 4C and D) was used to analyze Fab and Fc fragments generated following papain digestion of both whole antibodies (cleavage after $\mathrm{His}^{224}$ in the hinge region) [32]. As expected the ratio of peak areas was around 2 to 1 for A2CHM ( 2 Fab for $1 \mathrm{Fc}$, each having a mass of around $50 \mathrm{kDa}$ ). Conversely for $7 \mathrm{H} 2 \mathrm{HM}$, the $\mathrm{Fab} / \mathrm{Fc}$ ratio was $0.67: 1$. The Fab of $7 \mathrm{H} 2 \mathrm{HM}$ was collected and submitted to MALDI-TOF; the measured mass

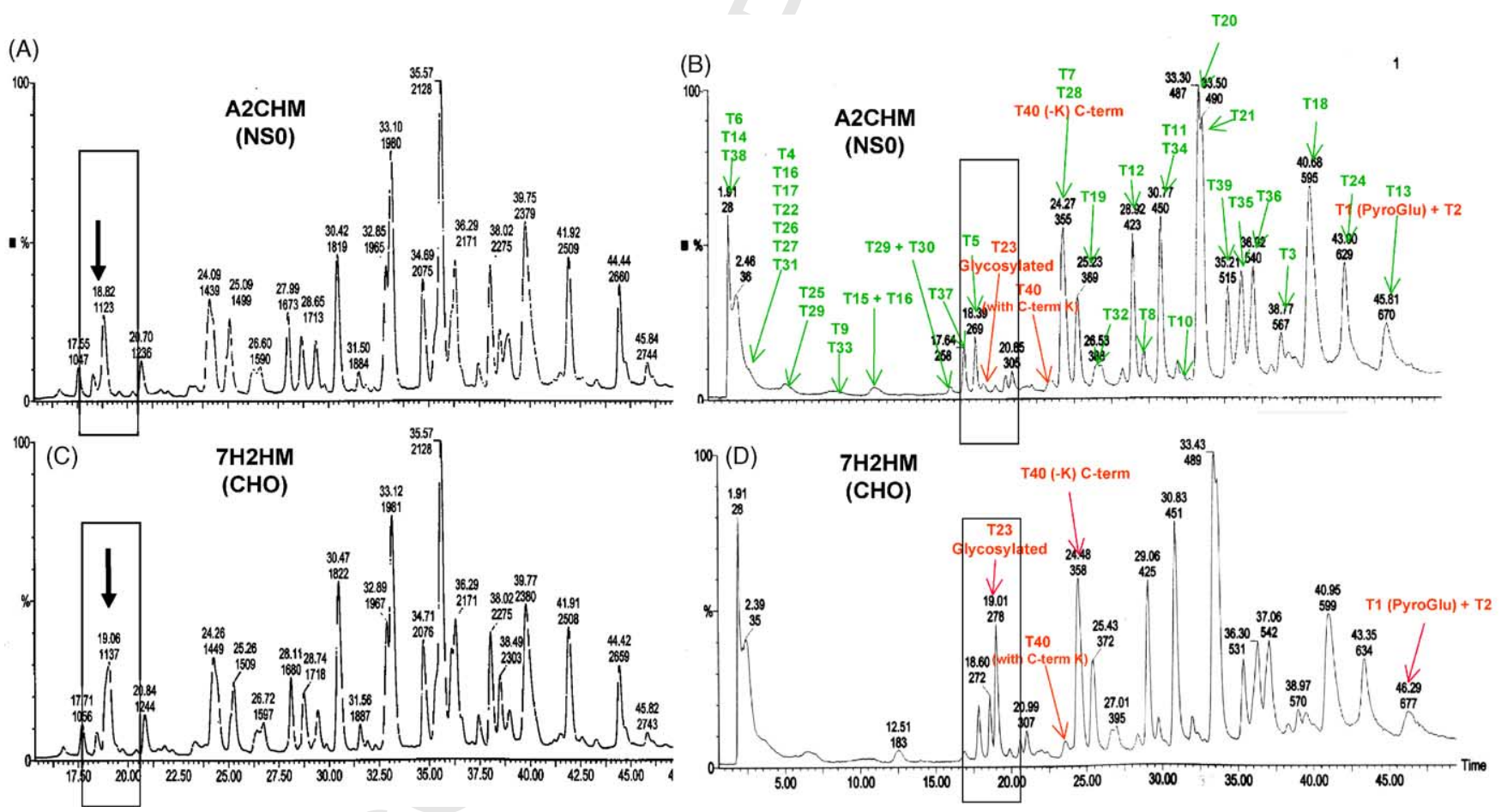

Fig. 5. Liquid chromatography ultra-violet and mass spectrometry analysis of heavy chains trypsin maps. Both $7 \mathrm{H} 2 \mathrm{HM}$ and A2CHM Heavy chains were trypsin-digested and analyzed by RP-HPLC with UV (A and C) and MS detection (B and D), respectively. 
Table 3

7H2HM and A2CHM heavy chains trypsin LC-MS maps

\begin{tabular}{|c|c|c|c|c|}
\hline Fragment & Sequence & $\begin{array}{l}\text { Calculated } \\
\text { mass }\end{array}$ & $\begin{array}{l}\text { Experimental mass } \\
7 \mathrm{H} 2 \mathrm{HM}(\mathrm{CHO})\end{array}$ & $\begin{array}{l}\text { Experimental mass } \\
\text { A2CHM(NS0) }\end{array}$ \\
\hline HT1.2 (1-44) & $\begin{array}{l}\mathrm{Q}^{1} \text { VQLQESGPGLVKPSETLSLTC } \\
\text { TVSGYSITGGYLWNWIR.QPPGK }\end{array}$ & 4835.5 & 4817.5 & 4817.4 \\
\hline HT3 (45-65) & GLEWIGYISYD ${ }^{55}$ GTNNYKPSLK & 2418.7 & 2418.5 & 2418.5 \\
\hline HT4 (66-67) & DR & 289.1 & 289.1 & 289.1 \\
\hline HT5 (68-72) & VTISR & 574.3 & 574.3 & 574.3 \\
\hline HT6 (73-76) & DTSK & 449.2 & 550.0 & 550.0 \\
\hline HT7 (77-82) & NQFSLK & 735.4 & 735.4 & 735.4 \\
\hline HT8 (83-98) & LSSVTAADTAVYYC ${ }^{96} \mathrm{AR}$ & 1746.8 & 1746.9 & 1746.9 \\
\hline HT9 (99-101) & YGR & 394.2 & 394.1 & 394.1 \\
\hline HT10 (102-121) & VFFDYWGQGTLVTVSSASTK & 2192.1 & 2192.0 & 2192.1 \\
\hline Intron-fragment 1 & VFFDYWGQGTLVTVSSGEWILCAWAQLCPTPR & 3718.3 & n.d. ${ }^{a}$ & - \\
\hline Intron-fragment 2 & SHGTTSLAASTK & 1160.3 & 1159.61 & - \\
\hline HT11 (122-123) & GPSVFPLAPSSK & 1185.6 & 1185.7 & 1185.7 \\
\hline HT12 (134-147) & STSGGTAALGC ${ }^{144}$ LVK & 1320.7 & 1320.7 & 1320.7 \\
\hline HT13 (148-210) & $\begin{array}{l}\text { DYFPEPVTVSWNSGALTSGVHTFPAVLQSSGLYS } \\
\text { LSSVVTVPSSSLGTQTYIC }{ }^{200} \text { NVNHKPSNTK }\end{array}$ & 6716.5 & 6716.4 & 6716.7 \\
\hline HT14 (211-213) & VDK & 360.2 & 360.1 & 360.1 \\
\hline HT15.16 (214-218) & R.VEPK & 627.4 & 627.4 & 627.4 \\
\hline HT17 (219-222) & $\mathrm{SC}^{220} \mathrm{DK}$ & 508.2 & 508.2 & 508.2 \\
\hline HT18 (223-248) & THTC ${ }^{226}$ PPC $^{229}$ PAPELLGGPSVFLFPPKPK & 2845.4 & 2845.2 & 2845.2 \\
\hline HT19 (249-255) & DTLM $^{252}$ ISR & 834.4 & 834.4 & 834.4 \\
\hline HT20 (256-274) & TPEVTC ${ }^{261}$ VVVDVSHEDPEVK & 2138.0 & 2138.1 & 2138.1 \\
\hline HT21 (275-288) & FNWYVD ${ }^{280}$ GVEVHNAK & 1676.8 & 1676.8 & 1676.8 \\
\hline HT22 (289-292) & TKPR & 500.3 & 500.3 & 500.3 \\
\hline HT23 (293-301) & $\begin{array}{l}\text { EEQYN }{ }^{297} \text { STYR } \\
\text { HT23 + G0F-NAcGlc } \\
\text { HT23 + G1F-NAcGlc } \\
\text { HT23 + G0F } \\
\text { HT23 + G1F } \\
\text { HT23 + G2F } \\
\text { HT23 + G2F+1 } \alpha \mathrm{G} \\
\text { HT23 + G2F+2 } \alpha \mathrm{G}\end{array}$ & $\begin{array}{l}1181.3 \\
2430.2 \\
2592.2 \\
2633.2 \\
2795.2 \\
2957.2 \\
3119.2 \\
3281.2\end{array}$ & $\begin{array}{r}\text { n.d. } \\
2431.3 \\
2593.4 \\
2634.4 \\
2796.5 \\
2958.5 \\
- \\
-\end{array}$ & $\begin{array}{r}\text { n.d. } \\
2431.2 \\
2593.3 \\
2634.7 \\
2796.5 \\
2958.6 \\
3121.7 \\
\text { n.d. }\end{array}$ \\
\hline HT24 (302-317) & VVSVLTVLHQDWLN ${ }^{315} \mathrm{GK}$ & 1808.1 & 1808.0 & 1808.0 \\
\hline HT25 (318-320) & EYK & 438.2 & 438.2 & 438.2 \\
\hline HT26 (321-322) & $\mathrm{C}^{321} \mathrm{~K}$ & 306.1 & 306.1 & 306.1 \\
\hline HT27 (323-326) & VSNK & 446.2 & 446.1 & 446.1 \\
\hline HT28 (327-334) & ALPAPIEK & 837.5 & 837.5 & 837.5 \\
\hline HT29.30 (335-340) & TISK.AK & 646.4 & 646.3 & 646.3 \\
\hline HT31 (341-344) & GQPR & 456.2 & 456.2 & 456.2 \\
\hline HT32 (345-355) & EPQVYTLPPSR & 1285.7 & 1285.7 & 1285.7 \\
\hline HT33 (356-360) & $\mathrm{EEM}^{358} \mathrm{TK}$ & 636.3 & 636.3 & 636.3 \\
\hline HT34 (361-370) & NQVSLTC ${ }^{367}$ LVK & 1160.6 & 1160.7 & 1160.9 \\
\hline HT35 (371-392) & GFYPSDIAVEWESN ${ }^{384}$ GQPENNYK & 2543.1 & 2543.2 & 2543.3 \\
\hline HT36 (393-409) & TTPPVLDSD ${ }^{401}$ GSFFLYSK & 1872.9 & 1873.0 & 1873.0 \\
\hline HT37 (410-414) & LTVDK & 574.3 & 574.3 & 574.3 \\
\hline HT38 (415-416) & SR & 261.1 & 261.3 & 261.3 \\
\hline HT39 (417-439) & WQQGNVFSC ${ }^{425}$ SVM $^{428}$ HEALHNHYTQK & 2800.3 & 2800.7 & 2800.7 \\
\hline HT40 (440-447) & SLSLSPGK & 787.4 & 787.0 & 787.0 \\
\hline HT40-K (440-446) & SLSLSPG $\left(-K^{447}\right)$ & 659.4 & 659.4 & 659.4 \\
\hline
\end{tabular}

${ }^{\mathrm{a}}$ n.d., not determined.

was the expected one without intron translation $48403 \mathrm{Da}$ for $48095 \mathrm{Da}$ calculated $(\Delta M=326 \mathrm{Da} ; 0.7 \%)$, assuming an $\mathrm{N}$ terminal PyroGlu ( $-18 \mathrm{Da}$ ) (Table 4). Surprisingly, no traces of an intron-containing Fab were seen on the chromatogram. Taken together, these observations suggest that the translated intron may be cleaved by papain. The papain hinge cleavage site is the $\mathrm{His}^{224}$ (EPKSCDKTḦ ${ }^{224} /$ TCPPCPAPLL). A cleavage site of the intron could also occur at the His present 601 in this sequence (GEWILCAWAQLCPTPRSH/GTTSLA), resulting in further non-specific digestion of the Fab and its "removal" from the HIC chromatogram. If 7H2HM is a mixture of three antibodies in a 17/33/50 ratio as suggested by RP-HPLC and by ES-TOF, papain digestion would result in $2 \mathrm{Fab}$ and $1 \mathrm{Fc}$ for the native antibody $(\times 17 \%), 1 \mathrm{Fab}$ and 


\section{A - Tryptic map}

$\begin{array}{ccc}\text {-YGR/VFFDYWGQGTLVTVSSGEWILCAWAQLCPTPR/SHGTTSLAASTK/GPSVFPLAPSSK / - } \\ \text { H-CDR3 } & \text { FrameWork } 4 & \text { Translated Intron } \\ C_{\mathrm{H}} 1\end{array}$

\section{$B$ - Theoretical heavy chain RNA splicing $\left(V_{H} / C_{H} 1\right)$}
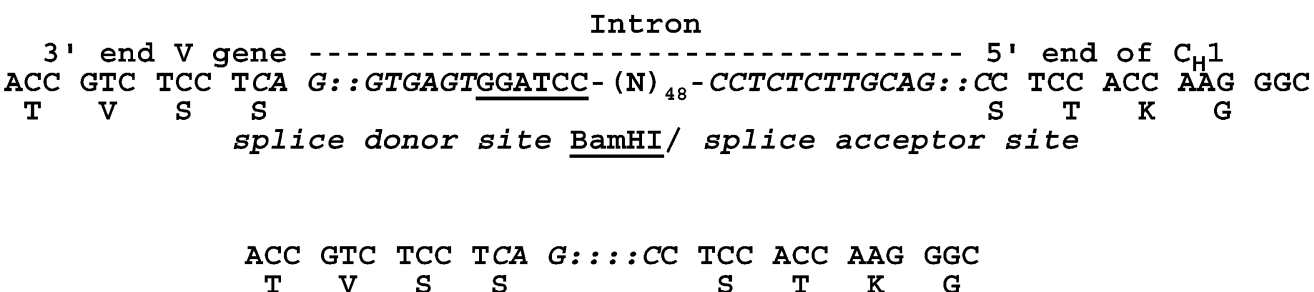

ACC GTC TCC TCA GCC TCC ACC AAG GGC

$\begin{array}{lllllllll}\mathrm{T} & \mathrm{V} & \mathrm{S} & \mathrm{S} & \mathrm{A} & \mathrm{S} & \mathrm{T} & \mathrm{K} & \mathrm{G}\end{array}$

Intron (24 aa) :

$2599 \mathrm{Da}$

$+(2 \times 57$ Da $)$

Intron (24 aa Red/alk): $2713 \mathrm{Da}$

Fig. 6. $7 \mathrm{H} 2 \mathrm{HM}$ intron between heavy chains variable and constant domains. Translated 24 amino acid intron localization and sequence (A); trypsin fragmentation and theoretical splicing mechanism (B).

$1 \mathrm{Fc}$ for the one intron antibody $(\times 33 \%)$ and $0 \mathrm{Fab}$ and 1 Fc for the two introns antibody $(\times 50 \%)$, which finally correspond well with the $0.67 \mathrm{Fab}$ for $1 \mathrm{Fc}$ observed on the papain digested 7H2HM HIC chromatogram (Fig. 4C).

\subsection{Glycosylation}

N-linked glycans of human IgG and of other species have been extensively characterized [16,44-49]. These glycans are mainly complex biantenary structures with core fucose and often terminated with sialic acid residues. Five types of monosaccharides units are usually present in human and hamster $N$-glycoproteins: galactose and mannose (=hexoses; 162.0 Da), fucose (=deoxyhexose; $146.1 \mathrm{Da}), N$-acetylglucosamine (=HexNac; 203.1 Da), $N$-acetylneuraminic acid [=NeuAc; NANA; sialic acid (anionic); 291.1 Da] and another sialic acid in mice $N$-glycolylneuraminic acid [=NeuGc; NGNA; 307.1 Da].

Table 4

7H2HM and A2CHM whole antibody, light and heavy chains, Fc and Fab analysis by MALDI-TOF and LC-TOF-MS

\begin{tabular}{|c|c|c|c|c|c|}
\hline Post-translational modification ${ }^{\mathrm{a}}$ : polypeptide sequence & $\operatorname{IgG} 1 \kappa$ & LC(red/alk) & HC(red/alk) & $\mathrm{Fab}$ & $\mathrm{Fc}$ \\
\hline \multirow[t]{2}{*}{ Calculated mass (Da) } & $149297(146375)$ & 24348 & $51229(49768)$ & 48095 (48113) & $53143(50185)$ \\
\hline & $\operatorname{IgG} 1 \kappa$ & LC(red/alk) & $\mathrm{HC}(\mathrm{red} / \mathrm{alk})$ & $\mathrm{Fab}^{\mathrm{b}}$ & $\mathrm{Fc}$ \\
\hline \multicolumn{6}{|l|}{ 7H2HM (CHO) } \\
\hline Experimental mass (Da) & 155126 & 24348 & 54671 & 48403 & 53316 \\
\hline \multirow[t]{2}{*}{ Difference of mass } & $5829(3.9 \%)$ & 0 & $3442(6.7 \%)$ & $307(0.6 \%)$ & $-173(0.3 \%)$ \\
\hline & IgG1к (two introns ) & LC(red/alk) & $\mathrm{HC}$ (red/alk, intron) & Fab & $\mathrm{Fc}$ \\
\hline \multicolumn{6}{|c|}{$7 \mathrm{H} 2 \mathrm{HM}(\mathrm{CHO})+$ "introns" $\left(1\right.$ or $2 \times 24$ amino-acids between $\left.\mathrm{V}_{\mathrm{H}} / \mathrm{C}_{\mathrm{H}} 1\right)$} \\
\hline Calculated mass (Da) & 154495 & - & 53924 & 50717 & - \\
\hline \multirow[t]{2}{*}{ Difference of mass } & $631(0.4 \%)$ & - & $746(1.4 \%)$ & Not isolated & - \\
\hline & $\operatorname{IgG} 1 \kappa$ & LC(red/alk) & $\mathrm{HC}(\mathrm{red} / \mathrm{alk})$ & Fab & Fc \\
\hline \multicolumn{6}{|l|}{ A2CHM (NS0) } \\
\hline Experimental mass (Da) & 149208 & 24348 & 51835 & Not performed & 53560 \\
\hline Difference of mass & $-87(0.1 \%)$ & 0 & $607(1.2 \%)$ & & $417(0.8 \%)$ \\
\hline
\end{tabular}

a HC.N-term PyroGlu (-18 Da), HC.C-term Lys (-128 Da), Asn ${ }^{297 ~ “ G 1 ” ~ g l y c o s y l a t i o n ~(+1607 ~ D a) . ~}$

b Only around $0.67 \%$ of the expected Fab amount, compared to the Fc (HIC). 

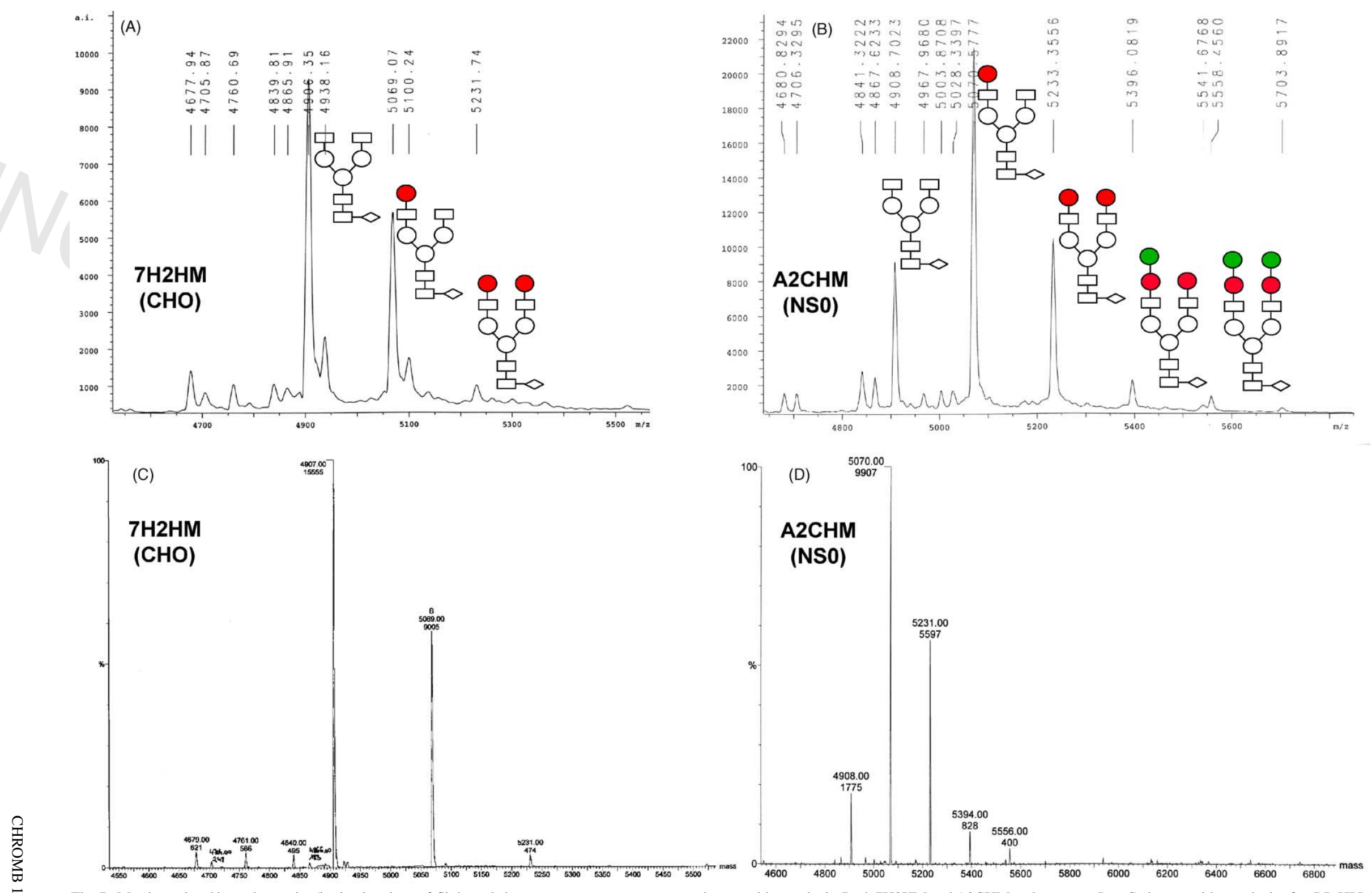

Fig. 7. Matrix-assisted laser desorption/ionization time-of-flight and electrospray mass spectrometry glycopeptides analysis. Both 7H2HM and A2CHM endoprotease Lys-C glycopeptides analysis after RP-HPLC purification by MALDI-TOF (A and B, respectively) or by direct LC-MS analysis and MaxEnt ${ }^{\mathrm{TM}}$ algorithm transformation (C and D). 
Table 5

7H2HM and A2CHM endoprotease Lys-C glycopeptides profiling by MALDI-TOF and LC-TOF-MS

\begin{tabular}{|c|c|c|c|c|c|}
\hline Carbohydrates & G0 & G1 & G2 & Mono $\alpha 1,3-G a l G a l$ & Di $\alpha 1,3-G a 1 G a l$ \\
\hline Calculated mass (Da) & 4906.2 & 5068.3 & 5230.5 & 5392.6 & 5554.7 \\
\hline \multicolumn{6}{|l|}{ 7H2HM } \\
\hline MALDI-TOF ratio (\%) & $4906.4(61)$ & $5069.1(36)$ & $5231.7(3)$ & - & - \\
\hline ES-TOF/MaxEnt ${ }^{\mathrm{TM}}$ ratio $(\%)$ & $4907.0(62)$ & $5069.0(36)$ & $5231.0(2)$ & - & - \\
\hline \multicolumn{6}{|l|}{ A2CHM } \\
\hline MALDI-TOF ratio (\%) & $4908.7(20)$ & $5070.6(51)$ & $5233.4(23)$ & $5396.1(4)$ & $5558.5(2)$ \\
\hline ES-TOF/MaxEnt ${ }^{\mathrm{TM}}$ ratio $(\%)$ & $4908.0(10)$ & $5070.0(54)$ & $5231.0(30)$ & $5394.0(4)$ & $5556.0(2)$ \\
\hline
\end{tabular}

The only consensus sequence for $\mathrm{N}$-glycosylation (Asn$\mathrm{X}$-Ser/Thr, where $\mathrm{X}$ is any amino acid except Pro) in $7 \mathrm{H} 2 \mathrm{HM}$ and A2CHM is asparagine 297 as for other IgGs [33]. Glycopeptides containing the glycosylated $\mathrm{Asn}^{297}$ were generated and analyzed, after trypsin (-R/EEQYN ${ }^{297} \mathrm{STYR} / \mathrm{V}-$ ; 9-mer) [35] or endoproteinase Lys-C cleavage (-K/TKPR EEQYN ${ }^{297}$ STYRVVSVLTVLHQDWLNGK/E-; 23-mer). The glycoform profile observed after endoprotease Lys-C digestion, by direct LC-TOF analysis after peak isolation by RP-HPLC and MALDI-TOF analysis are shown in Fig. 7. The three observed main peaks are interpreted as the so-called "G0" (HexNAc 4 Hex $_{3}$ DeoxyHex $\left._{1}\right)$, "G1" (HexNAc $\mathrm{Hex}_{4}$ DeoxyHex $\left._{1}\right)$ and "G2" forms $\left(\mathrm{HexNAc}_{4} \mathrm{Hex}_{5}\right.$ DeoxyHex $\left._{1}\right)$. They were present in both antibodies but in different ratios: $(61-62 \%, 36-36 \%$ and $3-2 \%)$ for $7 \mathrm{H} 2 \mathrm{HM}$ and (10-20\%, 51-54\% and 23-30\%) for A2CHM (Table 5). Two additional small glycoforms (HexNAc ${ }_{4} \mathbf{H e x}_{6}$ DeoxyHex $\left._{1}\right)$ and $\left(\mathrm{HexNAc}_{4} \mathbf{H e x}_{7} \mathrm{DeoxyHex}_{1}\right)$ were also identified for A2CHM with a $4 \%$ and $2 \%$ ratio, respectively, as previously reported for antibodies produced in NS0 cells [50].

\section{Discussion}

During the development of recombinant humanized antibodies directed against human IGF-1R, a CHO and a NS0 cell line producing 7H2HM and A2CHM MAbs, respectively, were generated. For early biological and analytical investigations, a single affinity chromatography step on protein A was used to purify $7 \mathrm{H} 2 \mathrm{HM}$ and A2CHM. A four-step chromatography process was designed for immunohistochemistry assays and to produce reference batches of antibodies, to setup quantitative dosages and for further pre-clinical development.

$7 \mathrm{H} 2 \mathrm{HM}$ and $\mathrm{A} 2 \mathrm{CHM}$ were investigated for microheterogeneties usually described for similar IgG products like N-terminal pyroglutamate formation; C-terminal Lys clipping and Asn-linked carbohydrates [23-25,29-33,35,41].

Analytical methods based on differences of masses (SDSPAGE and SEC) gave similar homogeneous pictures for both whole antibodies and after reduction, for both light and heavy chains. Size-exclusion chromatography was the method of choice to demonstrate the removal of dimers and aggre- gates during the purification process (in-process controls after each chromatography step) and during long-term storage [51]. IsoElectric focusing was used to determine 7H2HM and A2CHM isoelectric points (pI) and to analyze the isoform profiles. A2CHM displayed a main band with an isoelectric point of 8.7 which is a value close to reported $\mathrm{pI}$ for other therapeutic humanized IgG1 like MabCampath ${ }^{\mathrm{TM}} /$ alemtuzumab [26] and Herceptin ${ }^{\mathrm{TM}} /$ trastuzumab [23,25] as well as for the recently approved human Humira ${ }^{\mathrm{TM}} /$ adalimumab [29]. As a quality control method, IsoElectric focusing is primarily used to ensure the identity, consistency and stability of a protein when compared with reference material. The use of IEF stained with Coomassie Blue and scanned by densitometry provided a semi-quantitative approach for monitoring charged isoforms. The difference of pattern observed by IEF was initially attributed to differences of glycosylation that may occur when two different systems of expression are used [52]. This hypothesis was not confirmed by intact antibodies PNGase digestion and IEF analysis.

RP-HPLC based on differences of hydrophobicity and CIEX based on differences of charge, where investigated as complementary analytical methods. They clearly showed a difference of homogeneity for both antibodies. RP-HPLC was particularly useful to resolve and to quantify three families of peaks for 7H2HM, which were isolated and submitted to mass analysis by MALDI-TOF. Direct MALDI-TOF analysis as well as ES-MS confirmed that A2CHM had an experimental mass in agreement with the calculated one and that $7 \mathrm{H} 2 \mathrm{HM}$ was a mixture of three families of $\mathrm{IgG}$ having the expected mass and an excess of approximately 3000 and $6000 \mathrm{Da}$, respectively.

Mass spectrometry was also useful to demonstrate that this excess of mass was not located on the light chains but on the heavy chains: one-third had the expected mass and two-thirds of the heavy chains had around $3000 \mathrm{Da}$ excess of mass. The interpretation of HIC chromatogram of papain digested 7H2HM antibody was initially confusing, because the HIC-isolated Fab and Fc fragments were both found to have the expected masses.

Tryptic map analysis of the heavy chain of 7H2HM alone did not allow the identification of an additional peptide, which was subsequently shown to co-elute with a mixture of $\mathrm{Asn}^{297}$ containing glycopeptides. Furthermore, the compar- 
ative analysis of trypsin digested RP-HPLC maps of 7H2HM and $\mathrm{A} 2 \mathrm{CHM}$ did not show an obvious difference. Conversely, LC-MS with TIC detection showed the presence of an important additional peak. This peptide was isolated, submitted to mass measurement and microsequenced, leading to the identification of a partial intron fragment located between heavy chain variable and constant domains.

This 24-amino-acid intron was normally spliced but in the case of the $\mathrm{CHO}$ cell line used and vector for 7H2HM expression [CHO Dux B11 (dhfr -/+) cells], it only occurred for around $33 \%$ of the heavy chains. The calculated mass of this 24 mer reduced-alkylated peptide was $2713 \mathrm{Da}$ which approaches the approximately $3000 \mathrm{Da}$ excess of mass measured for the main part of 7H2HM heavy chain by two mass spectrometry methods. The second part of the intron (GEWILCAWAQLCPTPR) was not detected on the tryptic map. This may be explained by the exceptionally high hydrophobic character of this trypsin-digested 30mer peptide, in which half of the amino acids are hydrophobic (VFFDYWGQGTLVTVSSGEWILCAWAQLCPT). This hydrophobic character probably makes it difficult to be eluted from the RP-HPLC column.

The retrospective interpretation of the analytical data was in agreement with the presence of this translated intron in 7H2HM compared to A2CHM, which had the expected structure. SDS-PAGE and SEC of intact antibodies, which are very large proteins, were not able to resolve a difference of mass of $4 \%$. However, two bands were visible on the SDS-PAGE for reduced and alkylated $7 \mathrm{H} 2 \mathrm{HM}$ heavy chain (2\% difference of mass), the major band corresponding to an "intron" containing heavy chain and the minor to the expected heavy chain. The 24-amino-acid additional segment contains two charged amino acids (glutamic acid and histidine): the C-IEX heterogeneous chromatogram, the multi-band IEF gel and the ES-MS/MaxEnt spectrum are interpreted as a superposition of three families of antibodies (with 0,1 and 2 translated introns) overlapping isoforms with 0,1 and 2 lysines as for $\mathrm{A} 2 \mathrm{CHM}$ and other IgG1. The more acidic peak and band visible for A2CHM are either interpreted as deamidated variants (asparagine to aspartic acid hydrolyses contributing to one more negative charge) or negatively charged sialic acid minor glycoforms, as described for other antibodies [52]. Further analytical developments are in progress to investigate these hypotheses.

The mass spectrometry data obtained for $7 \mathrm{H} 2 \mathrm{HM}$ and A2CHM intact antibodies, reduced-alkylated light and heavy chain, and papain digested Fab and Fc fragments are summarized in Table 4. These data are in agreement with the expected structure for A2CHM and with the 24 amino-acid translated intron for the main family present in $7 \mathrm{H} 2 \mathrm{HM}$. These data also show that a mass accuracy of $0.1 \%$ [31,33], can be obtained even for $150 \mathrm{kDa}$ large protein and will thus be a target for quality control. From a biological point of view, the presence of this translated intron in 7H2HM had no impact on IGF-1R recognition and biological activity [14].
Glycosylation of $\mathrm{Asn}^{297}$ in both mammalian cell production systems was addressed by MALDI-TOF and LC-MS after trypsin and endoprotease Lys-C digestion. The three observed main peaks present in both expressions systems were interpreted as the so-called "G0", "G1" and "G2" glycoforms $[4,33,35]$. They were present in $7 \mathrm{H} 2 \mathrm{HM}$ and in A2CHM but in different ratios. Another difference in the case of A2CHM, was the presence of small amounts (2-4\%) of two specific glycoforms, with one or two further galactose $\alpha(1-3)$ linked, not normally present in either human nor hamster [52]. The micro-heterogeneity of IgG glycans affects biological functions such as complement dependent cytotoxicity (CDC), antibody-dependent cytotoxicity (ADCC) $[4,10,45]$, binding to various $\mathrm{Fc}$ receptors, binding to $\mathrm{Clq}$ protein and plasmatic half-life [53]: the presence or absence of $\mathrm{Asn}^{297}$ oligosaccharides affects ADCC and core fucosylation inversely correlates with ADCC [54], but galactosylation has no ADCC effect [55]. The micro-heterogeneity of human IgG glycans varies with age, gender and is often indicative of disease status [47], for example IgGs from rheumatoid arthritis patients contain more non-galactosylated oligosaccharides ("G0") than those from non-arthritic patients [56].

Complementary characterization of glycoforms by FACE (fluorophore-assisted carbohydrate electrophoresis), normal phase-HPLC with fluorescence detection and HPAEC-PAD (high-pH anion-exchange chromatography-pulsed amperometric detection) for negatively charged sialic acids [33] are planned as well as structure-activity relationship studies [14].

\section{Conclusion}

In summary, we herein described the extensive analytical and structural characterization of a new humanized monoclonal antibody. This immunoglobulin is specific for human insulin-like growth factor-1 receptor, a tyrosine kinase receptor over-expressed in many tumor cell types and will be investigated in clinical trials. The two most current mammalian cell production systems, namely $\mathrm{CHO}$ and NSO cells were used to generate material for biological evaluation, and the resulting $7 \mathrm{H} 2 \mathrm{HM}$ and $\mathrm{A} 2 \mathrm{CHM}$ antibodies were characterized side-by-side.

The first-line analytical methods like SDS-PAGE, SEC and IEF $[18,26,57]$ were not stringent enough to demonstrate the occurrence of an unexpected translational event in the case of the $\mathrm{CHO}$ clone. However, the combination of mass spectrometry and the less frequently used RP-HPLC of large proteins, is able to clearly visualize this event. This emphasizes that it is essential to use orthogonal methods based on different physical and chemical separation properties, even at the early discovery stage to validate structural expectation or identify anomalies. Furthermore, the elucidation of the unknown structure was greatly facilitated by the availability of a well-characterized antibody exhibiting the correct sequence 
and a comparison of both peptide maps by liquid chromatography and mass spectrometry detection instead of ultra-violet detection $[25,58]>$.

Finally, all the herein presented analytical methods will be used during pharmaceutical development for quality control and for stability studies of this new promising therapeutic antibody.

\section{Uncited reference}

[54].

\section{Acknowledgment}

Authors wish to thanks Drs T. Wurch, O. Léger and P. Pauwels for helpful discussions and Mrs. C. Catry for secretarial help with the manuscript.

\section{References}

[1] M. Berger, V. Shankar, A. Vafai, Am. J. Med. Sci. 324 (2002) 14.

[2] J.M. Reichert, Curr. Opin. Mol. Ther. 4 (2002) 110.

[3] T.J. Torphy, Curr. Opin. Biotechnol. 13 (2002) 589.

[4] L. Presta, Curr. Opin. Struct. Biol. 13 (2003) 519.

[5] O.H. Brekke, I. Sandlie, Drug Nat. Rev. Discov. 2 (2003) 52.

[6] E. Drewe, R.J. Powell, J. Clin. Pathol. 55 (2002) 81.

[7] M. Trikha, L. Yan, M.T. Nakada, Curr. Opin. Biotechnol. 13 (2002) 609.

[8] I.D. Davis, M. Jefford, P. Parente, J. Cebon, J. Leuk. Biol. 73 (2003) 3.

[9] J.S. Ross, K. Gray, G.S. Gray, P.J. Worland, M. Rolfe, Am. J. Clin. Pathol. 119 (2003) 472.

[10] P. Carter, Nat. Rev. Cancer 1 (2001) 118.

[11] S.J. Moschos, C.S. Mantzoros, Oncology (Basel) 63 (2002) 317.

[12] D. LeRoith, C.T. Roberts Jr., Cancer Lett. 195 (2003) 127.

[13] P.T. Jones, P.H. Dear, J. Foote, M.S. Neuberger, G. Winter, Nature 321 (1986) 522.

[14] L. Goetsch, A. Gonzalez, O. Leger, P. Pauwels, J.F. Haeuw, N. Corvaia, Int. J. Cancer, in press.

[15] L. Chu, D.K. Robinson, Curr. Opin. Biotechnol. 12 (2001) 180.

[16] H.E. Chadd, S.M. Chamow, Curr. Opin. Biotechnol. 12 (2001) 188.

[17] L.M. Barnes, C.M. Bentley, A.J. Dickson, Biotechnol. Bioeng. 73 (2001) 261.

[18] J.M. Brass, K. Krummen, C. Moll-Kaufmann, Pharm. Acta Helv. 71 (1996) 395.

[19] R.L. Fahrner, H.L. Knudsen, C.D. Basey, W. Galan, D. Feuerhelm, M. Vanderlaan, G.S. Blank, Biotechnol. Gene. Eng. Rev. 18 (2001) 301.

[20] A.P. Jonsson, Cellular, Mol. Life Sci. 58 (2001) 868.

[21] M. Lokteff, C. Klinguer-Hamour, E. Julien, D. Picot, L. Lannes, T.N. Nguyen, J.Y. Bonnefoy, A. Beck, Biologicals 29 (2001) 123.

[22] N. Dagouassat, J.F. Haeuw, V. Robillard, F. Damien, C. Libon, N. Corvaïa, F. Lawny, T.N. Nguyen, J.Y. Bonnefoy, A. Beck, J. Immunolog. Methods 251 (2001) 151.

[23] G. Hunt, K.G. Moorhouse, A.B. Chen, J. Chromatogr. A 744 (1996) 295.

[24] G. Hunt, T. Hotaling, A.B. Chen, J. Chromatogr. A 800 (1998) 355.

[25] R.J. Harris, B. Kabakoff, F.D. Macchi, F.J. Shen, M. Kwong, J.D. Andya, S.J. Shire, N. Bjork, K. Totpal, A.B. Chen, J. Chromatogr. B: Biomed. Sci. Applic. 752 (2001) 233.

[26] J. Phillips, A. Drumm, P. Harrison, P. Bird, K. Bhamra, E. Berrie, G. Hale, Cytotherapy 3 (2001) 233.
[27] M. Adamczyk, J.C. Gebler, C.A. Harrington, A.F. Sequeira, Eur. Mass. Spectrom. 5 (1999) 165.

[28] K.G. Moorhouse, W. Nashabeh, J. Deveney, N.S. Bjork, M.G. Mulkerrin, T. Ryskamp, J. Pharm. Biomed. Anal. 16 (1997) 593.

[29] L.C. Santora, I.S. Krull, K. Grant, Anal. Biochem. 275 (1999) 98.

[30] M. Weitzhandler, D. Farnan, J.S. Rohrer, N. Avdalovic, Proteomics 1 (2001) 179.

[31] A.J. Alexander, D.E. Hughes, Anal. Chem. 67 (1995) 3626.

[32] D.S. Ashton, C.R. Beddell, D.J. Cooper, S.J. Craig, A.C. Lines, R.W. Oliver, M.A. Smith, Anal. Chem. 67 (1995) 835.

[33] G.D. Roberts, W.P. Johnson, S. Burman, K.R. Anumula, S.A. Carr, Anal. Chem. 67 (1995) 3613.

[34] R. Mhatre, J. Woodard, C. Zeng, Rapid Commun. Mass Spectrom. 13 (1999) 2503

[35] L.E. Matamoros Fernandez, D.E. Kalume, L. Calvo, M.M. Fernandez, A. Vallin, P. Roepstorff, J. Chromatogr. B: Biomed. Sci. Applic. 752 (2001) 247.

[36] A. Beck, M.C. Bussat, C. Klinguer-Hamour, L. Goetsch, J.P. Aubry, T. Champion, E. Julien, J.F. Haeuw, J.Y. Bonnefoy, N. Corvaia, J. Peptide Res. 57 (2001) 528.

[37] A. Beck, L. Goetsch, T. Champion, M.C. Bussat, J.P. Aubry, C. Klinguer-Hamour, J.F. Haeuw, J.Y. Bonnefoy, N. Corvaia, Biologicals 29 (2001) 293

[38] W. Zhang, L.A. Marzilli, J.C. Rouse, M.J. Czupryn, Anal. Biochem. 311 (2002) 1.

[39] A. Beck, N. Zorn, M.C. Bussat, J.F. Haeuw, N. Corvaïa, T.N. Nguyen, J.Y. Bonnefoy, A. Van Dorsselaer, J. Peptide Res. 55 (2000) 24.

[40] F.J. Shen, M.Y. Kwong, R.G. Keck, R.J. Harris, in: D.R. Marshak (Ed.), Techniques in Protein Chemistry, Vol. 7, Academic Press, 1996, 275.

[41] X.M. Lam, J.Y. Yang, J.L. Cleland, J. Pharm. Sci. 86 (1997) 1250.

[42] J. Cacia, R. Keck, L.G. Presta, J. Frenz, Biochemistry 35 (1996) 1897.

[43] S. Tsunasawa, S. Nakura, T. Tanigawa, I. Kato, J. Biochem. 124 (1998) 778.

[44] N. Jenkins, R.B. Parekh, D.C. James, Nat. Biotechnol. 14 (1996) 975.

[45] P. Umana, J. Jean-Mairet, R. Moudry, H. Amstutz, E. Bailey, Nat. Biotechnol. 17 (1999) 176

[46] J.P. Kunkel, D.C. Jan, M. Butler, J.C. Jamieson, Biotechnol. Prog. 16 (2000) 462.

[47] T.S. Raju, J.B. Briggs, S.M. Borge, A.J. Jones, Glycobiology 10 (2000) 477.

[48] J.A. Saba, J.P. Kunkel, D.C.H. Jan, W.E. Ens, K.G. Standing, M. Butler, J.C. Jamieson, H. Perreault, Anal. Biochem. 305 (2002) 16

[49] S. Krapp, Y. Mimura, R. Jefferis, R. Huber, P. Sondermann, J. Mol. Biol. 325 (2003) 979.

[50] D.M. Sheeley, B.M. Merrill, L.C. Taylor, Anal. Biochem. 247 (1997) 102.

[51] J.L. Cleland, X. Lam, B. Kendrick, J. Yang, T.H. Yang, D. Overcashier, D. Brooks, C. Hsu, J.F. Carpenter, J. Pharm. Sci. 90 (2001) 310.

[52] R. Jefferis, BioPharm 14 (2001) 19.

[53] W.F. Dall' Acqua, R.M. Woods, E.S. Ward, S.R. Palaszynski, N.K. Patel, Y.A. Brewah, H. Wu, P.A. Kiener, S. Langermann, J. Immunol. 169 (2002) 5171.

[54] R.L. Shields, J. Lai, R. Keck, L.Y. O’Connell, K. Hong, Y.G. Meng, S.H. Weikert, L.G. Presta, J. Biol. Chem. 277 (2002) 26733.

[55] T. Shinkawa, K. Nakamura, N. Yamane, E. Shoji-Hosaka, Y. Kanda, M. Sakurada, K. Uchida, H. Anazawa, M. Satoh, M. Yamasaki, N. Hanai, K. Shitara, J. Biol. Chem. 278 (2003) 3466.

[56] R. Malhotra, M.R. Wormald, P.M. Rudd, P.B. Fischer, R.A. Dwek, R.B. Sim, Nat. Med. 1 (1995) 237.

[57] A.H. Guse, A.D. Milton, H. Schulze-Koops, B. Muller, E. Roth, B. Simmer, H. Wachter, E. Weiss, F. Emmrich, J. Chromatogr. A 661 (1994) 13

[58] M. Wan, F.Y. Shiau, W. Gordon, G.Y. Wang, Biotechnol. Bioeng. 62 (1999) 485. 


\section{CHROMB 13462}

935

Subject Index:

936

CHO cells, NSO cells, Peptide mapping, Glycopeptide mapping

\section{Compound Index:}

940

941 Recombinant monoclonal antibodies

942 Insulin-like growth factor-1 receptor 